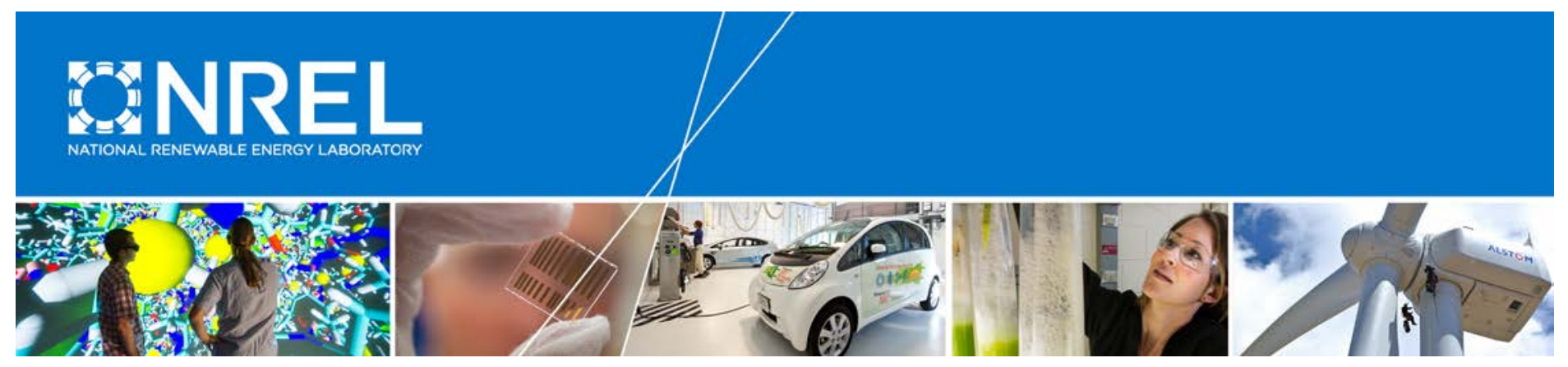

\title{
Check the Stack: An Enabling Framework for Resilient Microgrids
}

Jeffrey J. Cook, Christina Volpi, Erin Nobler, and Kyle Flanegin

National Renewable Energy Laboratory

NREL is a national laboratory of the U.S. Department of Energy Office of Energy Efficiency \& Renewable Energy Operated by the Alliance for Sustainable Energy, LLC

This report is available at no cost from the National Renewable Energy Laboratory (NREL) at www.nrel.gov/publications.

Technical Report

NREL/TP-6A20-71594

November 2018

Contract No. DE-AC36-08G028308 


\title{
Check the Stack: An Enabling Framework for Resilient Microgrids
}

\author{
Jeffrey J. Cook, Christina Volpi, Erin Nobler, \\ and Kyle Flanegin
}

National Renewable Energy Laboratory

\section{Suggested Citation}

Cook, Jeffrey J., Christina Volpi, Erin Nobler, and Kyle Flanegin. 2018. Check the Stack: An Enabling Framework for Resilient Microgrids.

Golden, CO: National Renewable Energy Laboratory.

NREL/TP-6A20-71594. https://www.nrel.gov/docs/fy19osti/71594.pdf.

NREL is a national laboratory of the U.S. Department of Energy

Office of Energy Efficiency \& Renewable Energy

Operated by the Alliance for Sustainable Energy, LLC

This report is available at no cost from the National Renewable Energy Laboratory (NREL) at www.nrel.gov/publications.

National Renewable Energy Laboratory 15013 Denver West Parkway

Golden, CO 80401

303-275-3000 • www.nrel.gov

\section{Technical Report}

NREL/TP-6A20-71594

November 2018

Contract No. DE-AC36-08GO28308 


\section{NOTICE}

This work was authored by the National Renewable Energy Laboratory, operated by Alliance for Sustainable Energy, LLC, for the U.S. Department of Energy (DOE) under Contract No. DE-AC36-08G028308. Funding provided by U.S. Department of Energy Office of Energy Efficiency and Renewable Energy Solar Energy Technologies Office. The views expressed in the article do not necessarily represent the views of the DOE or the U.S. Government.

This report is available at no cost from the National Renewable Energy Laboratory (NREL) at www.nrel.gov/publications.

U.S. Department of Energy (DOE) reports produced after 1991 and a growing number of pre-1991 documents are available free via www.OSTI.gov.

Cover Photos by Dennis Schroeder: (left to right) NREL 26173, NREL 18302, NREL 19758, NREL 29642, NREL 19795.

NREL prints on paper that contains recycled content. 


\section{Acknowledgments}

This work was funded by the Solar Energy Technologies Office and was implemented by the Solar Technical Assistance Team Network (STAT). STAT provides technical assistance to state and local governments relating to solar technology- and policy related-decisions. This report is associated with a request from the North Carolina Department of Public Safety relating to resilient energy solutions for critical infrastructure.

The authors would like to thank all the interviewees for contributing their expertise to this study including: Mike Gravely (California Energy Commission), Veronica Szczerkowski (Connecticut Department of Energy and Environmental Protection), Chris Lotspeich (Celtic Energy), Andrew Reid (Consolidated Edison), Cat Wong (Entergy) Larisa Dobriansky (General Microgrids), Kevin Fok (LG Chem Power), James Gignac and Sameer Doshi (Office of the Illinois Attorney General), Faith Huntington (Maine Public Utilities Commission), Gerry Bingham

(Massachusetts Department of Energy Resources), Diane Hewittt and Mike Winka (New Jersey Board of Public Utilities), Dave Crudele and John Saintcross (New York State Energy Research and Development Authority), Sam Watson (North Carolina Utilities Commission), Diane Broad and Adam Schultz (Oregon Department of Energy), Clark Wiedetz (Siemens Industry), Rich Wakeland (Texas Public Utilities Commission), and Anne Margolis and Ed McNamara (Vermont Department of Public Service).

We would also like to thank the following individuals for their review of this work: Jaquelin Cochran, Elizabeth Doris, Eliza Hotchkiss, Jeff Logan, and Doug Arent from the National Renewable Energy Laboratory, Gouhui Yuan and Ammar Qusaibaty from the Department of Energy, and two anonymous external reviewers. Finally, we would like to thank Mollie Putzig and Stacy Buchanan (National Renewable Energy Laboratory) for their editing and graphics support. 


\section{List of Acronyms}

APTA

CBECS

DHS

EPA

ESPC

GW

ICE

IEEE

MW

NREL

PV

RPS

TIF

TWh
American Public Transportation Association

Commercial Buildings Energy Consumption Survey

U.S. Department of Homeland Security

Environmental Protection Agency

energy savings performance contracting

Gigawatt

Interruption Cost Estimate

Institute of Electrical and Electronics Engineers

Megawatt

National Renewable Energy Laboratory

photovoltaics

Renewable portfolio standard

tax increment financing

terawatt hours 


\section{Executive Summary}

Natural disasters have illustrated the fragility of critical infrastructure including emergency services, healthcare, and water treatment during long-term electricity outages. One pathway to increase the resilience of critical infrastructure is developing microgrids, particularly those that incorporate solar photovoltaics (PV) and energy storage. This is because PV and storage may prolong facility operation during an electrical grid outage longer than a more conventional system operating alone (Anderson et al. 2017). Building on the Department of Energy's (DOE) (2012) definition of a microgrid, this report defines a resilient microgrid as a set of interconnected facilities that include critical infrastructure and distributed energy resources with the ability to island from the grid during an outage among other features. Research is limited with respect to how much critical infrastructure could benefit from microgrids, how many states have pursued this prioritization approach, and what policies need to be in place to support more widespread deployment. This report explores each of these questions to offer the industry and policymakers a clearer understanding of the opportunity for resilient microgrids and a framework for decisionmakers to achieve their market objectives.

Critical infrastructure varies from location to location making it difficult to assess the scope of this market. To explore this question, this analysis compiled certain facility-level data from seven of the 16 critical infrastructure sectors defined by the U.S. Department of Homeland Security (DHS), including:

- Emergency services

- Energy (e.g., electricity, oil, and natural gas)

- Government Facilities (e.g., education, election infrastructure, and national icons)

- Healthcare

- Information technology

- Transportation

- Water and wastewater systems.

At least 15 million critical infrastructure facilities are associated with these seven sectors across the United States. The facilities in the dataset roughly represent a cumulative load of 570 terawatt hours representing about $15 \%$ of national load. The loss of these facilities would have 
significant impacts on societal function, including economic and human losses. Considering only economic losses associated with an outage, as is most typical in the commercial and industrial sector, a four-day outage at all 15 million critical facilities could result in an economic impact exceeding $\$ 700$ billion. If all these facilities faced such an outage, it is likely that overall societal costs, would be much higher. Therefore, policymakers may be interested in mitigating outage risks at critical infrastructure, and one pathway is resilient microgrids.

The authors identified 28 policies, programs, or initiatives that are directly related to supporting resilient microgrid deployment in various technology and metering configurations (i.e., single meter or multiple meters) across 13 states. Most states have adopted grant, loan, and other financing programs to reduce the cost of microgrids and support deployment. The remaining policies are divided across four categories including microgrid roadmapping, energy market reform, resiliency retrofits, and utility regulation.

Given that few states have adopted resilient microgrid policies and the lack of policy is cited as a barrier to deployment (DNV GL 2015), the goal of this analysis was to inform state-level policymakers on what policies may help create a resilient microgrid market, regardless of the owner of the system. Relying on the policy stacking literature, interviews were conducted with 22 subject matter experts to build a resilient microgrid policy framework. The policy stack for resilient microgrids is outlined in Figure ES-1 and includes market preparation, market creation, and market expansion elements.

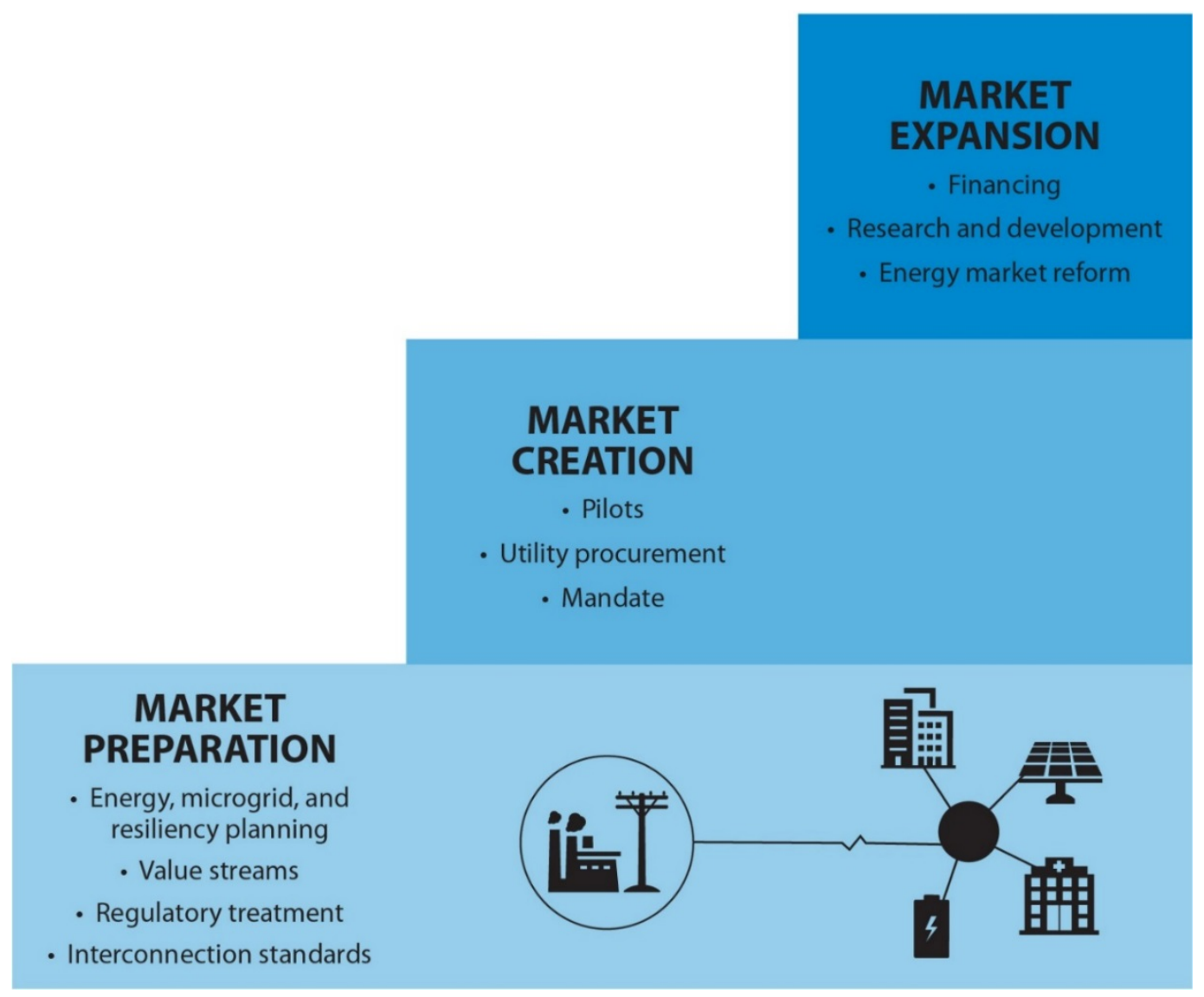

Figure ES-1. Resilient microgrid policy stack 
To build a market, policymakers might wish to first consider, foundational market preparation policies. This step may include conducting or supporting resiliency planning to identify relevant critical infrastructure facilities that might benefit from microgrid deployment. The state may then wish to review its interconnection policies to ensure that microgrids have a clear pathway to connect and island from the electrical grid. After establishing these market preparatory policies, the state might consider a range of market creation policies ranging from resilient microgrid pilot programs to mandating deployment at certain critical facilities. Finally, states might consider a range of options for expanding resilient microgrid markets. For example, a state could expand financing options or support research and development in new technology or business models that might result in lower cost systems and more widespread deployment.

The policies included in this report are not exhaustive and individual states considering employing microgrids to enhance resilience and other energy policy goals will need to evaluate a wide variety of issues when developing their own policies unique to their market context. Even so, this report offers a framework that interested states might consider, if they wish to enable a resilient microgrid market. 


\section{Table of Contents}

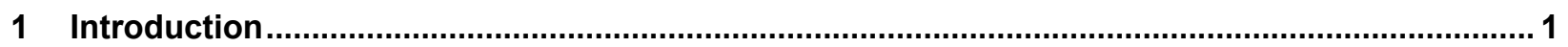

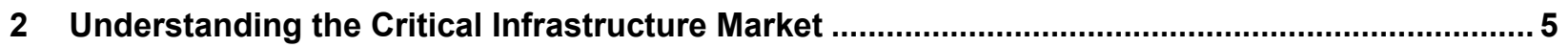

3 Policy Landscape Relating to Resilient Microgrids .............................................................. 9

4 Building a Market Framework for Resilient Microgrids ............................................................ 12

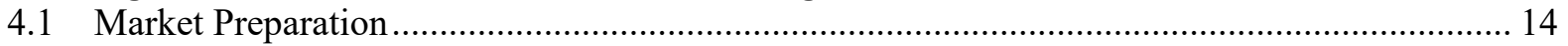

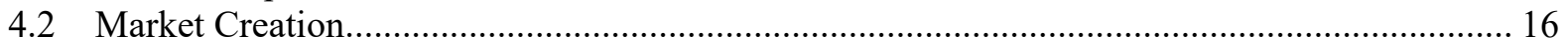

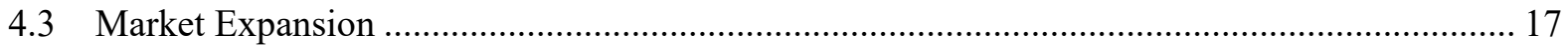

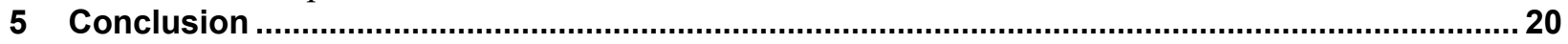

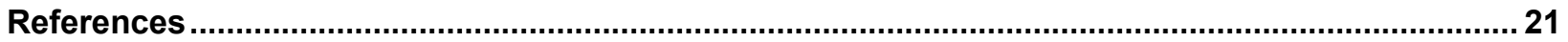

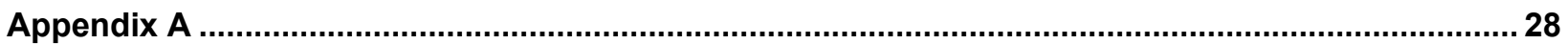

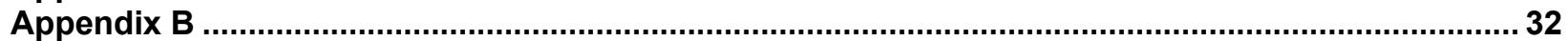

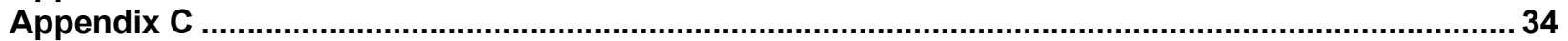




\section{List of Figures}

Figure ES-1. Resilient microgrid policy stack vi Figure 1. Annual commissioned microgrid capacity by technology through 2016 (recreated from Saadeh 2016) 2

Figure 2. Average annual electricity load for certain critical infrastructure subsectors by system or facility

Figure 3 States with microgrid-related policies as of December 2017

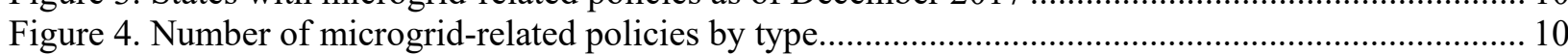

Figure 5. Policy stacking framework (recreated from Krasko and Doris 2013) ..................................... 13

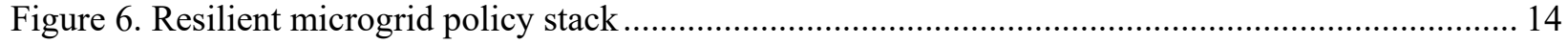

\section{List of Tables}

Table 1. Critical Infrastructure Sectors and related Facilities.............................................................. 6

Table 2. Annual Electricity Load for Certain Critical Infrastructure Subsectors.......................................2 28

Table 3. Estimated Outage Cost by Critical Infrastructure Subsector System or Facility ........................ 31

Table 4. Identified State Policies and Programs Directly Affecting Microgrid Deployment ..................... 34 


\section{Introduction}

Severe weather has illustrated the vulnerabilities within the nation's power sector. Hurricane Sandy in 2012 caused 8.5 million people to lose power for up to a week (Executive Office of the President 2013). In 2017 Hurricane Maria cut power to all 3.4 million citizens in Puerto Rico and 90 days after landfall, 35\% of the island was still without power (FEMA 2018). Severe weather is a leading cause of power outages across the country (Executive Office of the President 2013) and the frequency and cost of weather-related natural disasters exceeding $\$ 1$ billion has steadily increased since 2004. The six most active weather years have occurred since 2008 and the cumulative cost of natural disasters in 2017 exceeded $\$ 300$ billion, surpassing the previous record of $\$ 200$ billion set in 2005 (NOAA 2018a).

Storm costs stem from physical damages as well as economic losses from business interruption, among other factors (NOAA 2018b). Policymakers have taken steps to mitigate physical risks by requiring buildings to withstand high winds or flooding (Kusisto and Campo-Flores 2017). More recently, the adoption of microgrids to continue operations amidst broader grid outages has increased as both a mitigation and adaptation strategy. There are a variety of definitions for what constitutes a microgrid. The U.S. Department of Energy (DOE) defines a microgrid as "a group of interconnected loads and distributed energy resources within clearly defined electrical boundaries that acts as a single controllable entity with respect to the grid. A microgrid can connect and disconnect from the grid to enable it to operate in both grid-connected or islandmode" (DOE 2012, pg. 84). Microgrids can come in many forms and one classification approach is based on the system's interconnection to the grid as follows:

- Level 1 is a single customer microgrid with one meter.

- Level 2 is a single customer in a campus setting with multiple meters.

- Level 3 is a microgrid that serves multiple customers across several meters (New Jersey Board of Public Utilities 2016).

The concept of a microgrid is not new, but in recent years United States microgrid capacity has significantly increased from about 700 Megawatts (MW) in 2010 to more than 2 Gigawatts (GW) in 2017 (Saadeh 2016; Metelitsa 2017). ${ }^{1}$ Microgrid systems have been deployed in a variety of contexts, including military installations, industrial facilities, and universities, to provide more reliable electricity, reduce supply risks, and in some cases reduce costs (Metelitsa 2017). ${ }^{2}$ Microgrids typically include distributed fossil fuel generators running on natural gas and/or diesel, but renewable energy capacity incorporated within microgrids has increased from about $4 \mathrm{MW}$ in 2008 to $164 \mathrm{MW}$ in 2016 (see Figure 1). Photovoltaics (PV) account for $73 \%$ of this renewable capacity.

\footnotetext{
${ }^{1}$ This deployment coincides with a variety of research and development projects into microgrid technology commercialization and integration. For example, the Department of Energy supports research related to microgrid blackstart capability (Thomas 2017), design, customer adoption, and cost reduction (Office of Electricity 2018).

2 The cost of microgrid projects can influence interest in this technology solution and these costs vary by microgrid design $(\$ 1,000 / \mathrm{kW}-\$ 4,400 / \mathrm{kW})$ and are evolving as the market matures (Saadeh 2016; Metelista 2017).
} 


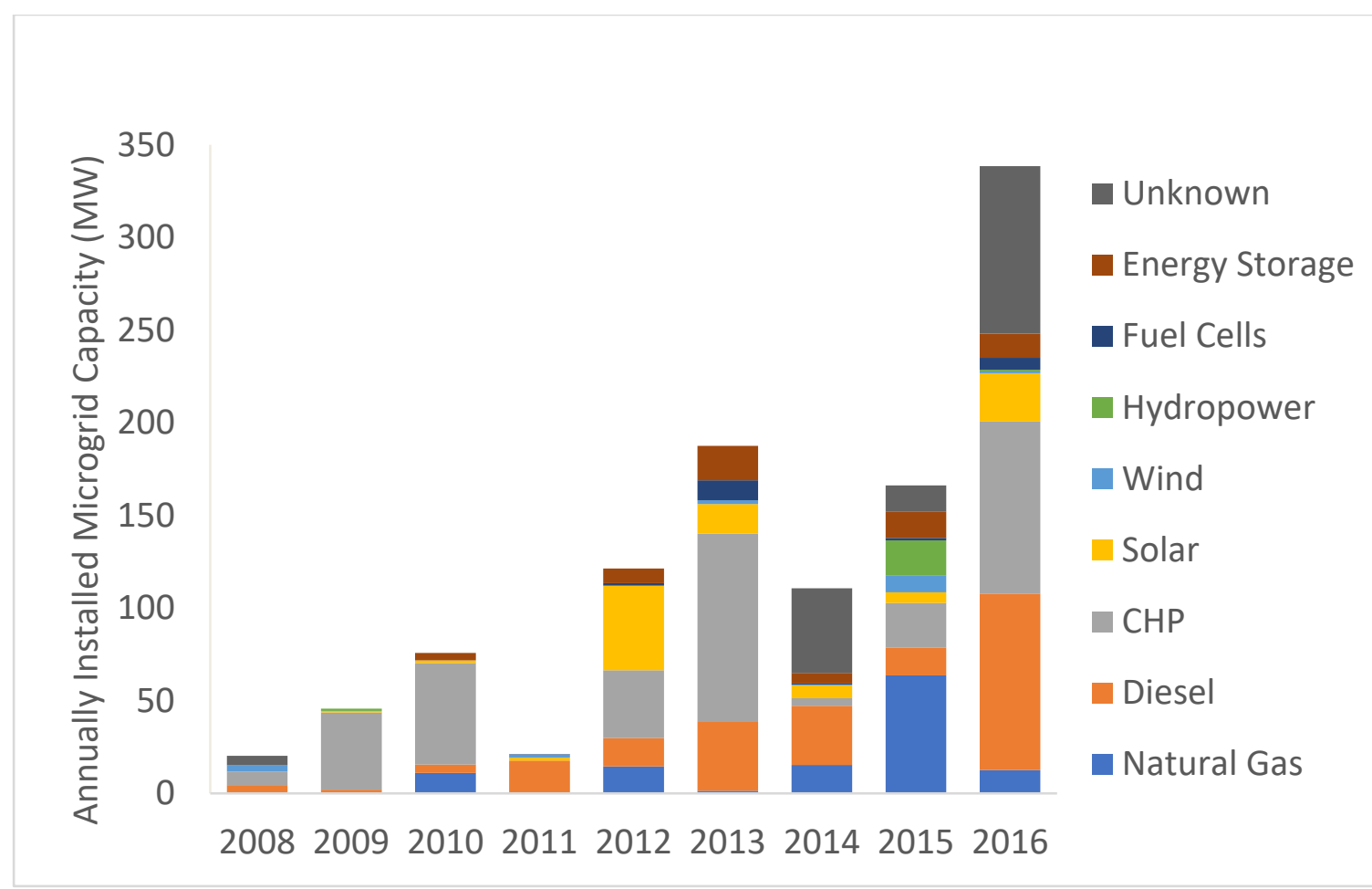

Figure 1. Annual commissioned microgrid capacity by technology through 2016 (recreated from Saadeh 2016)

Incorporating renewable energy, such as PV, into a microgrid may offer a variety of benefits over a microgrid served by fossil-fuels alone. ${ }^{3}$ Renewable energy can prolong operation of a facility during a long-term grid outage, especially in a scenario where the renewable energy system incorporates battery storage. For example, an analysis of a modeled telecommunications facility using a hybrid solar, storage, and diesel system was estimated to survive 1.8 days longer without grid electricity than a diesel system operating alone (Anderson et al. 2017). Renewable energy also produces zero emission electricity that can provide environmental and public health benefits. This electricity generation may also provide an economic benefit to participating customers if surplus electricity is sold to an electric service provider or systems are used to provide grid services such as demand response during normal operations.

Prolonged operation during a grid disruption relates to the resilience value offered by PV. Resilience in the context of energy systems can be defined as "the ability to anticipate, prepare for, and adapt to changing conditions and withstand, respond to, and recover rapidly from disruptions through adaptable and holistic planning and technical solutions" (Hotchkiss et al. 2016). There are a wide variety of resilient energy solutions that can be incorporated at critical infrastructure such as microgrids or conventional diesel generator sets. Despite this technological diversity each resilience solution has a few key components: onsite electricity generation, islanding controls, black start capability, and energy storage solutions. ${ }^{4}$ For a facility to maintain energy supplies during a grid outage, it must have local electricity generation that can provide

\footnotetext{
${ }^{3}$ When considering resilient energy system configurations, these benefits need to be weighed against other factors such as cost and technical potential among other contextual factors not addressed in this report.

${ }^{4}$ These are just three critical components of many that ensure an energy project is resilient.
} 
power to all, or a portion, of the facility's load during the outage. In addition, this generation must be equipped with islanding controls that allow the onsite/local energy resource to provide electricity only to the facility and not export back to the broader grid. Islanding controls ensure the safety of electrical grid workers, such as linemen, that may be returning service to customers. Finally, onsite systems must have the ability to start generating electricity absent the broader electrical grid, as well as store power that is generated onsite. This is because grid outages can be sudden or unexpected requiring the distributed resources to respond absent grid power, in the form of blackstart capabilities. Energy storage, such as a battery system, is useful when integrating onsite renewable energy generation to store power when it is being generated (e.g., with solar power this would be during daylight hours) and allow for the use of power when the resource is not available (e.g., during nighttime hours when the sun is not shining).

Some facilities, like military bases, have a history of adopting resilient energy solutions because of the acknowledgement that reliable power is essential to continuity of operations. Government officials have also established mandatory back up generation requirements for certain critical facilities to withstand short-term outages (typically fewer than 72 hours). For example, 17 types of medical providers, including hospitals, hospice, and transplant centers must follow the Emergency Preparedness Requirements for Medicare and Medicaid Participating Providers and Suppliers that require emergency and standby power systems in the form of emergency generators in accordance with NFPA 99, NFPA 101, and NFPA 110 (Medicare and Medicaid Emergency Preparedness Rule 2016; CMS 2017). Other designated facilities may need to comply with NFPA 708 and adopt and maintain backup generation to operate at a minimum for 72 hours, or throughout a longer-term outage (Murck 2016). ${ }^{5}$

Despite these preventive measures, many facilities may still lack sufficient backup generation. For example, the failure of insufficient backup generation at a nursing home in Florida contributed to 12 deaths from heat-related complications (Ostroff 2017; Nehamas and Koh 2018). In addition, the aftermath of natural disasters has demonstrated the limitations associated with the most common form of backup generation: diesel generators. For example, during Hurricane Maria recovery efforts, hospitals in Puerto Rico had to close because diesel fuel reserves were exhausted and could not be replenished (Allen 2017). Some states have sought to improve resilience at these and other critical facilities by adopting polices that incentivize the inclusion of critical infrastructure in resilient microgrids. For the purposes of this report, resilient microgrids are defined as any type of microgrid (Level 1, 2, or 3) that incorporates the above resilient elements, distributed generation (e.g., renewable energy and battery storage), and critical infrastructure. ${ }^{6}$

Interest in improving resiliency is emerging, and the goal of this report is to help policymakers better understand what critical infrastructure is, what resilient microgrid policies have been adopted, and how interested policymakers might sequence policy to enable a market. To address these questions, the authors conducted a literature review on critical infrastructure and resilient microgrid policy and completed 22 interviews with representatives from state regulatory agencies, project developers, utilities, and other subject matter experts. The policy stacking

\footnotetext{
${ }^{5}$ Some facilities may be directed to withstand a 14-day outage, as dictated by the United States Army (Secretary of the Army 2017).

${ }^{6}$ For a more thorough discussion of the technologies and related configurations that could be used in a resilient microgrid see Rezkallah et al. (2017) and Anderson et al. (2017).
} 
framework (Krasko and Doris 2013) was then used to structure this data and demonstrate how policymakers interested in deploying resilient microgrids might sequence policy to achieve their goals. The results of this analysis are structured as follows:

- Section 2 provides an overview of resources available on the potential market opportunity and economic impact associated with critical infrastructure across the United States.

- Section 3 discusses the current policy landscape for resilient microgrids with attention to the state policy employed to enable deployment.

- Section 4 builds a policy stack for resilient microgrids that can then be used by interested policymakers as a guide when considering policy.

- Section 5 offers a conclusion and pathways for future research. 


\section{Understanding the Critical Infrastructure Market}

Though there has been a concerted effort in the United States to protect critical infrastructure from natural disasters and human threats since 1988 (Riedman 2016), a definition of critical infrastructure was not codified in federal statute until the passage of the United States PATRIOT Act of 2001. This law defines critical infrastructure as "systems and assets, whether physical or virtual, so vital to the United States that the incapacity or destruction of such systems and assets would have a debilitating impact on security, national economic security, national public health or safety, or any combination of those matters." 7

The United States Department of Homeland Security (DHS), tasked with implementing the law, has subsequently identified 16 critical infrastructure sectors, including emergency services, energy, healthcare, information technology, transportation, and water and wastewater systems, among others. ${ }^{8}$ Though DHS has identified these sectors, neither the PATRIOT Act nor DHS, has identified what systems or assets fit this definition within each sector (Moteff and Parfomak 2004; Ladnier 2017). This ambiguity is also prevalent internationally, making it challenging to identify what specific facilities qualify as critical infrastructure broadly (OECD 2008; Melkunaite et al. 2016). In the context of the United States, individual facilities can be designated as critical infrastructure by private entities, as well as local, state, or federal officials. Each of these policymakers may also have varying perspectives on the types of facilities that should be considered critical. One designation pathway is the DHS's Regional Resiliency Assessment Program where DHS works with the private sector, local and state governments, and other stakeholders, to identify infrastructure of regional significance. ${ }^{9}$ This and other decentralized approaches result in critical infrastructure facility lists that vary depending on the local context. As one example, Clark County, Nevada, designated local dams and schools as critical infrastructure, as well as casinos on the Las Vegas Strip (Urban Environmental Research LLC). Though there have been some efforts related to narrowing the definition of critical infrastructure, particularly through weighting a set of critical criteria or focusing on cascading effects of outages, these methods have not been universally adopted (Popescu and Simion, 2012; Reidman 2016).

Because the types of facilities designated as critical can vary from location-to-location, and DHS does not publicly distribute its listing of designated critical infrastructure for national security purposes, the scope of the critical infrastructure sector is unclear. This information gap can be problematic for both policymakers and developers. Policymakers may not be aware of how much critical infrastructure is in their state, what facilities may be vulnerable to long-term electricity outages, and what effect outages may have on services or societal functionality. At the same time, private developers may not be able to make important business decisions regarding which markets or critical infrastructure sectors are priority areas for enhancing societal benefits.

The goal of this paper is not to clarify the critical infrastructure sector nationwide. Rather, the intent is to offer policymakers and other stakeholders some perspective on how many facilities might be considered "critical," how reliant they are on electricity, and how grid outages may impact services. Collectively, this information may help inform decision-making processes that

\footnotetext{
${ }^{7}$ Section 1016 of the USA PATRIOT Act (P.L.107-56).

${ }^{8}$ For a discussion of all 16 critical infrastructure sectors see: https://www.dhs.gov/critical-infrastructure-sectors.

${ }^{9}$ For more information on this program see: https://www.dhs.gov/regional-resiliency-assessment-program.
} 
relate to enabling policy and market participation for resilient microgrids. Relying on publicly available data, it is possible to address these goals for certain facilities associated with seven of the 16 critical infrastructure sectors identified by DHS. Table 1 describes the facilities and data sources employed for each critical sector included in this analysis (for detailed methodology and assumptions see Appendix A).

Table 1. Critical Infrastructure Sectors and related Facilities

\begin{tabular}{|c|c|c|c|}
\hline Sector & Facility Type & $\begin{array}{l}\text { Total Facilities } \\
\text { or Systems }\end{array}$ & Key Data Sources \\
\hline $\begin{array}{l}\text { Information } \\
\text { Technology }\end{array}$ & Datacenters & 14.7 million & Shehabi et al. 2016 \\
\hline $\begin{array}{l}\text { Water and } \\
\text { Wastewater Systems }\end{array}$ & $\begin{array}{l}\text { Wastewater treatment } \\
\text { Public water systems }\end{array}$ & 85,000 & $\begin{array}{l}\text { Pabi, Amarnath, Goldstein, and Reekie } \\
2013\end{array}$ \\
\hline Government Facilities & K-12 Schools & 129,000 & $\begin{array}{l}\text { Environmental Protection Agency (EPA) } \\
\text { Portfolio Manager Technical Reference }\end{array}$ \\
\hline Emergency Services & $\begin{array}{l}\text { Police Departments } \\
\text { Fire Stations }\end{array}$ & 70,000 & Multiple Sources \\
\hline Healthcare & Hospitals & 5,600 & $\begin{array}{l}\text { EPA Portfolio Manager Technical } \\
\text { Reference }\end{array}$ \\
\hline Transportation & $\begin{array}{l}\text { Heavy Rail } \\
\text { Sea Ports } \\
\text { Airports } \\
\text { Gas Stations } \\
\text { Buses and other } \\
\text { commuter transit }\end{array}$ & 1,800 & $\begin{array}{l}\text { American Public Transportation } \\
\text { Association } \\
\text { EPA Portfolio Manager Technical } \\
\text { Reference }\end{array}$ \\
\hline Energy & Oil Refineries & 139 & Energy Information Administration \\
\hline
\end{tabular}

Across the sectors analyzed in this study, there are nearly 15 million critical infrastructure facilities or systems (See Table 1 and Appendix A). Most of these facilities are datacenters, ranging from small data servers located in commercial buildings to hyperscale server farms such as those managed by Google and Amazon. After datacenters, K-12 schools are the most common facility, followed by water and wastewater systems, and emergency services (i.e., police and fire stations).

Given the dependence critical infrastructure has on electricity, it is essential to understand electricity consumption across facilities. Collectively, these facilities have an estimated, average annual electricity demand exceeding 570 terawatt hours (TWh) representing about $15 \%$ of load based on 2017 electricity sales (for detailed methodology and assumptions see Appendix A). ${ }^{10}$ Figure 2 shows energy loads within each facility category. While datacenters are the most prevalent facilities they are not the highest energy consumers. Schools (K-12) and hospitals have the highest electricity loads, followed by datacenters. Most of the transportation-related industries are the least electricity intensive.

\footnotetext{
${ }^{10}$ EIA (2018) estimates total electricity retail sales in 2017 were 3,682 TWh.
} 


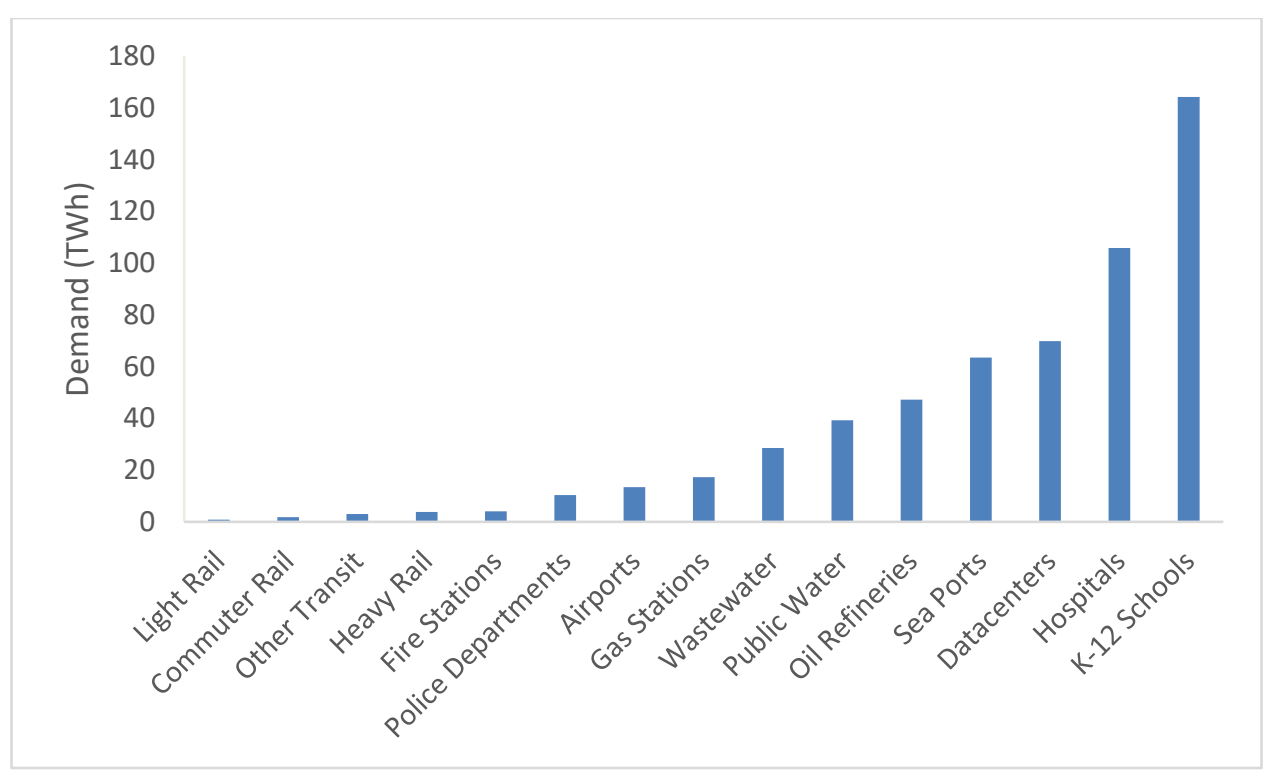

Figure 2. Average annual electricity load for certain critical infrastructure subsectors by system or facility

Lawrence Berkeley National Laboratory's Interruption Cost Estimate (ICE) calculator is a respected tool to estimate the direct cost of electricity outages for certain rate classes including commercial and industrial customers. ${ }^{11}$ ICE approximates that a typical large commercial and industrial customer with annual loads exceeding $50 \mathrm{MWh}$ may face a $\$ 40,000$ economic loss associated with a four-hour interruption as compared to $\$ 166,000$ loss for a 16-hour interruption (Sullivan, Schellenberg, and Blundell 2015). These economic loss estimates for commercial and industrial facilities were applied to the critical facilities data set to assess the potential economic impact of outages at critical facilities. Results indicate that a four-hour outage at all the facilities in the data set might result in an economic impact of $\$ 39$ billion, while a 16-hour outage could come with a $\$ 178$ billion cost (for detailed methodology and assumptions see Appendix A).

Though ICE does not report typical economic costs of long-term outages, it has been used on a case-by-case basis for this purpose. For example, one analysis of a hypothetical long-term outage (four days to three weeks) in Southern Orange County, California, resulted in four to 15 times higher costs than a 16-hour outage scenario (SDG\&E 2015). Applying the lower order of magnitude adder to the critical infrastructure outage estimated in this case suggests that a fourday outage might correspond with a direct cost of $\$ 713$ billion.

These estimates are a rough and highly speculative approximation of the potential economic impacts associated with a large-scale grid outage for all critical infrastructure. These estimated impacts assume that all load at each facility is "critical load." Critical load refers to the electricity required for the facility to provide essential services. In many cases, critical facilities will not need electricity to serve full load, and rather just a portion to provide essential services. For example, hospitals may designate operating rooms and heating and ventilation load as critical and certain plug loads as noncritical. In addition, many facilities have backup generation to withstand shorter term outages, which could further mitigate economic impacts. Finally, it is

\footnotetext{
${ }^{11}$ For more information on the ICE calculator see: http://www.icecalculator.com/index.html.
} 
possible that datacenters are located within other critical facilities such as hospitals, so these estimates may be double counting some demand and related economic losses. Finally, it is highly unlikely that all critical infrastructure would experience an outage at the same time nationwide. Nevertheless, this example demonstrates that outages at critical infrastructure facilities, especially in a long-term scenario, would result in significant economic damages. ${ }^{12}$

While high level, this preliminary assessment offers three insights. First, the definition of critical infrastructure varies from location to location, so effectively understanding resiliency needs will be dependent on the local context, as well as associated threats and vulnerabilities. Second, the millions of critical facilities included in this nationwide assessment are likely spread across many states and localities. Third, the economic impact of short-term outages at these facilities may range from $\$ 39$ to $\$ 178$ billion dollars. Though long-term economic impacts are difficult to quantify, they could exceed $\$ 700$ billion. Given these findings, state policymakers may wish to consider enabling policy to support improved resilience at these facilities and one such pathway is deploying resilient microgrids.

\footnotetext{
${ }^{12}$ Economic losses are also not the only costs associated with a disaster, human and other social losses, which are
} quantified separately, can increase the overall costs of outages at critical facilities. 


\section{Policy Landscape Relating to Resilient Microgrids}

Legislators in some states have already developed a market environment that enables resilient microgrid deployment. This section surveys the policy landscape to clarify which states have adopted policy and what these efforts were designed to do. The intent is to provide decisionmakers and other stakeholders perspective on some of the options available, while building a foundation for the broader policy framework outlined in Section 4.

Many policies can have direct and indirect effects on microgrids and the resilience of critical infrastructure. For example, state legislators can enact laws that require certain critical facilities to adopt backup generation to withstand grid outages for certain periods of time. In addition, policymakers can adopt energy efficiency, distributed energy, and grid modernization incentives that might improve the economics of microgrid projects. It is not the goal of this section to offer an exhaustive list of the policies that will impact critical infrastructure and resilient microgrid projects in a state. Rather, the goal is to highlight the policies, programs, and initiatives (hereafter referred to as policies) that have been specifically designed to support resilient microgrids as defined in Section 1.

The list of state policies included in this analysis were developed through a qualitative review of existing literature and interviews. This approach is reflective of the rapidly evolving nature of this field and varying experience with the use and deployment of resilient microgrids. The literature review focused on identifying microgrid policies published in market reports (Saadeh 2016; Metelitsa 2017), legislation databases, state agency webpages, and the popular press. The interviews with 22 subject matter experts including state regulators, developers, and utilities spanned 16 states and were conducted with senior project managers, directors, and engineers. The interviews were semi-structured, where interviewees were asked a series of questions to understand existing microgrid policies, key deployment barriers, and the role policy can play in addressing those barriers (See Appendix B for the list of interview questions). Through this process, 28 policies across 13 states were identified that directly affect microgrids (See Appendix $\mathrm{C}$ for more detailed information on each policy). As shown in Figure 3, most states with microgrid-related policies are located on the coastlines, while seven of the 13 states are clustered in the Northeast. 


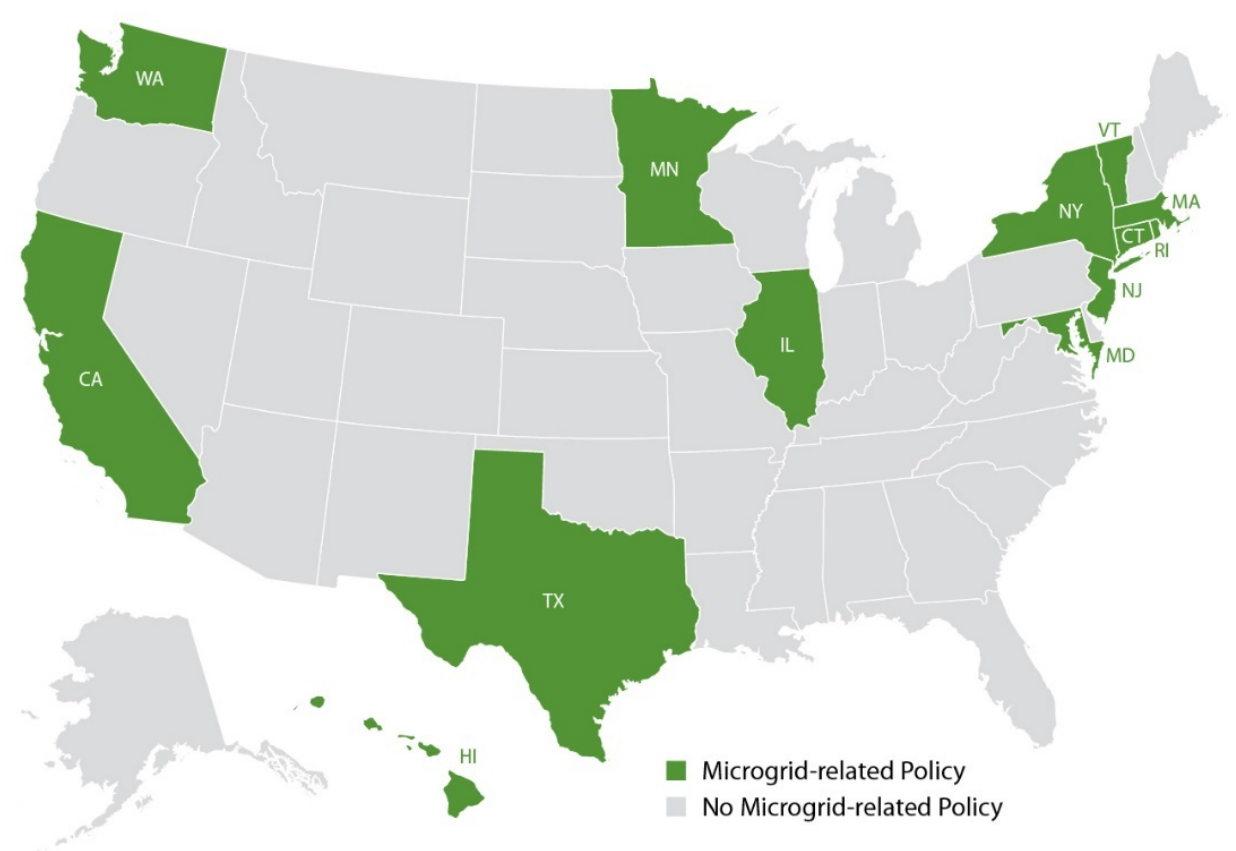

Figure 3. States with microgrid-related policies as of December 2017

After reviewing the content of each policy, they were organized into one of five categories based on best fit including: energy market reforms, grants, loans and other financing programs;

microgrid roadmapping; resiliency retrofits; and utility regulation (See Figure 4). Most states have adopted grant, loan, and other financing programs. Efforts relating to microgrid roadmaps are the second most common category, followed by energy market reform, resiliency retrofits, and utility regulation.

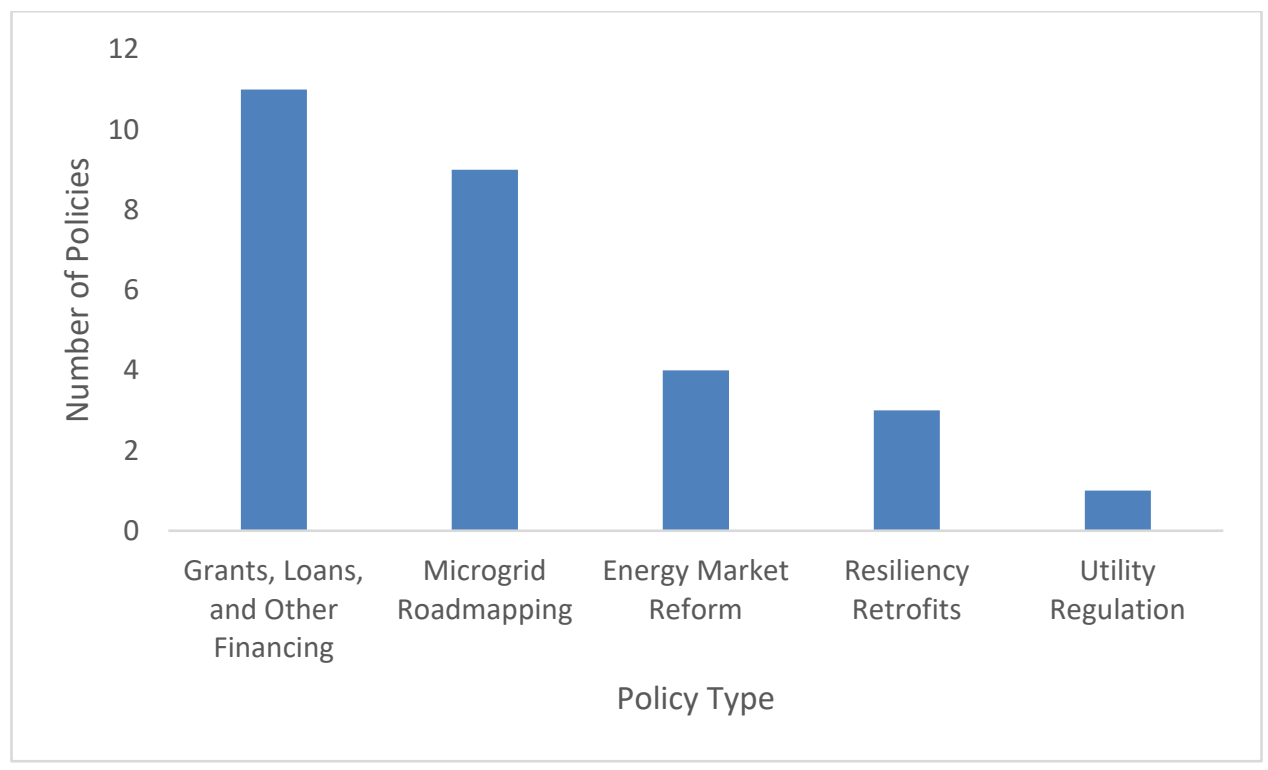

Figure 4. Number of microgrid-related policies by type

The grants, loans, and other financing category includes 11 policies spread across seven states designed to reduce the cost of resilient microgrids and support deployment. Three states (Massachusetts, New Jersey, and New York) have offered grant funding in stages, initially 
providing funding for feasibility studies, followed by engineering, and finally full implementation. For example, New York funded 83 feasibility studies in 2015 and then in 2017 funded full engineering design and business planning efforts for 11 projects. In the third phase of its program, New York will support the full implementation of selected projects. Another three states (California, Connecticut, and New Jersey) have adopted grant programs that did not allocate funding in phases, rather projects were selected for full funding at the outset. Finally, four states have provided direct grant funding or financial support for individual microgrid projects, in lieu of a competitive solicitation, including the NJ TRANSIT GRID in New Jersey, the Empire State Plaza in New York, the Stafford Hill project in Vermont, and the Microgrid and Clean Energy Technology Center in Washington State.

Seven states (California, Maryland, Massachusetts, Minnesota, New Jersey, New York, and Rhode Island) have commissioned what, for the purposes of this analysis, are categorized as microgrid roadmaps. These roadmaps evaluate how microgrids operate within a state's legal, regulatory, and financial frameworks and provide recommendations for future microgrid deployment. In some cases, these roadmaps are focused specifically on resilient microgrids.

Four states have adopted policies relating to energy market reforms that could enable microgrid deployment including Hawaii, Illinois, New York, and Rhode Island. These initiatives are designed to evaluate energy markets broadly and how a state might best achieve its energyrelated objectives, including resilience. Hawaii, Illinois, and Rhode Island are just beginning their efforts, while New York's Reforming the Energy Vision has been ongoing since 2014. Though these efforts have not yet resulted in direct microgrid policies, given the objectives of these initiatives it is plausible that market reforms will be included that address this topic area.

The resiliency retrofits category includes policies designed to improve resilience at existing facilities. All three policies in this category originate in Texas, which requires certain designated critical facilities like hospitals and wastewater treatment facilities to consider adopting combined heat and power systems to operate a full 14 days after a grid outage. If the investment is costeffective, the facility may install the equipment per the guidelines established by the Texas State Energy Conservation Office.

The utility regulation category includes one policy from Connecticut, which exempts certain municipal microgrids from utility regulation and allows project infrastructure to cross public rights-of-way.

This survey of the policy landscape provides two key findings: 1) comparatively few states have adopted any microgrid-related policies, programs, or initiatives and 2) those states that have adopted policy have taken different approaches to enable the market. The overall lack of supportive policy and regulation has been identified by microgrid developers and other stakeholders as one of the top barriers to future microgrid deployment (DNV GL 2015). Therefore, policymakers may benefit from a more in-depth discussion of the policies they could adopt to enable a resilient microgrid market in their state, as well as the key components that could be included. 


\section{Building a Market Framework for Resilient Microgrids}

Policymakers can pursue a variety of approaches to enable markets, but not all target the same barriers. The literature suggests that policy sequencing, also known as policy stacking, is an important process where policymakers adopt market reforms in a step-wise fashion that address barriers incrementally (Nsouli, Rached, and Funke 2005; Demont and Rizzo 2012; Krasko and Doris 2013; Meckling, Sterner, and Wagner 2017). The idea is that policymakers adopt lower cost and impact policies first that open a potential market, before enacting more complex, higher impact policies that further achieve their objectives. This concept has been fruitfully applied in a variety of market contexts including agriculture (Asiedu-Saforo 1989; Demont and Rizzotto 2012; Daugbjerg 2009), financing and economic reform (Spooner et al 1991; Soyibo 1997; Nsouli, Rached, and Funke 2005), trade (World Bank 1994), and more recently energy markets (Krasko and Doris 2013; Meckling, Sterner, and Wagner 2017).

The impact of policy sequencing can vary based on the policy area in question (Nsouli, Rached, and Funke 2005). Krasko and Doris (2013) were some of the first to apply the policy stacking concept in the context of energy and concluded that strategically sequencing distributed solar policy had a positive and significant effect on overall deployment. This correlation has persisted in subsequent empirical tests that account for market, technical potential, and other contextual differences across states (Krasko and Doris 2013; Steward, Doris, Krasko, and Hillman 2014; Steward and Doris 2014). Subsequently, Meckling, Sterner, and Wagner (2017) have argued that policy stacking has helped policymakers achieve their objectives in broader energy markets by helping reduce political and technical barriers. The goal here is to generate a policy stack that policymakers might consider to achieve their own resilient microgrid objectives.

Though all markets and related policy stacks are different, appropriate policies can be categorized into three general categories: market preparation, creation, and expansion (See Figure 5). Market preparation policies are designed to identify and address institutional barriers that may limit a technology's market access. For example, interconnection policies that clarify how distributed PV or microgrids might be connected to the electrical grid represent one type of market preparation policy. Market creation policies then spur direct private investment in clean energy, such as mandating the deployment of resilient microgrids for certain facilities. Market expansion policies are designed to reduce investment costs or otherwise foster widespread deployment. Tax incentives to offset technology costs are one example of this type of policy. States that adopt market preparation policies, followed by market creation and expansion policies are expected to have more success achieving their policy goals than other states taking a more piecemeal approach or adopting policies out of sequence (Krasko and Doris 2013). 


\section{MARKET}

\section{EXPANSION}

support widespread

deployment

\section{MARKET \\ CREATION}

foster private sector

investment

\section{MARKET \\ PREPARATION}

remove institutional barriers

to market access

Figure 5. Policy stacking framework (recreated from Krasko and Doris 2013)

A variety of factors can influence technology adoption including policy design, regulatory context, and market interest, among others (Nsouli, Rached, and Funke 2005; Krasko and Doris 2013). In this context, policy sequencing is an important part of market development and states may benefit from understanding what policies might support achieving their resilient microgrid objectives. This section relies on the literature and insights from interviews to generate a policy stack for resilient microgrids as summarized in Figure 6. Each section describes key state policies that could support a resilient microgrid market. 


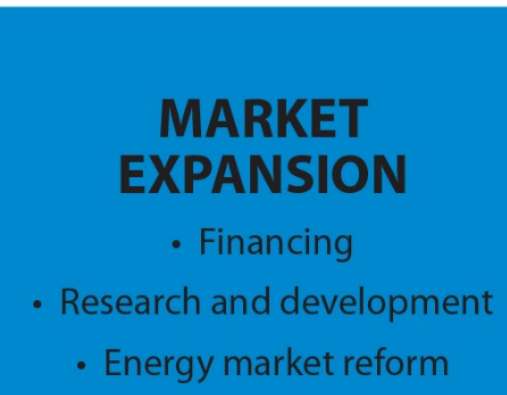

\section{MARKET}

CREATION

- Pilots

- Utility procurement

- Mandate

\section{MARKET PREPARATION}

- Energy, microgrid, and resiliency planning

- Value streams

- Regulatory treatment

- Interconnection standards

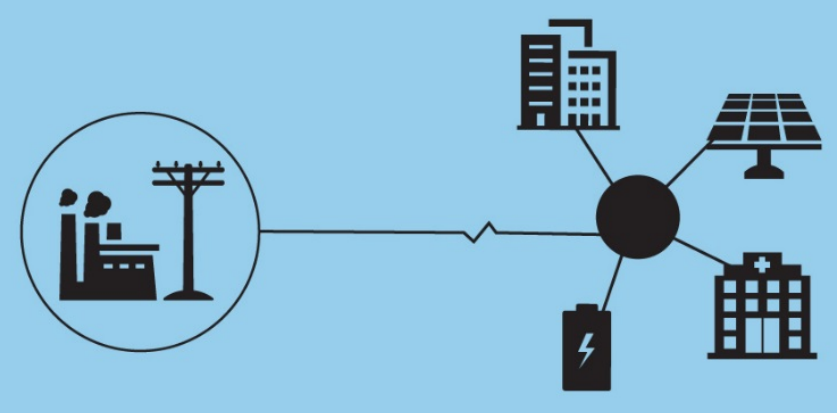

Figure 6. Resilient microgrid policy stack

\subsection{Market Preparation}

As mentioned previously, the market preparation component is designed to remove institutional barriers to market access. These policies are considered foundational; without them it may be difficult or impossible to build a market for resilient microgrids.

To begin, a state might consider incorporating the concept of a microgrid and its potential benefits in their existing planning processes for energy and resilience. Interviewees suggested this was an important first step for clarifying the opportunity for resilient microgrid deployment, creating a path and timeline for addressing deployment barriers, and achieving state policy objectives. To date, seven states have published microgrid roadmapping studies that consider the barriers and opportunities for microgrids in their market context. These studies also offer policy recommendations for resolving identified challenges and roadblocks to private developer participation. Although such studies are an important step, interviewees suggested that policymakers should consider microgrids in more comprehensive planning efforts. For example, 42 states have published an energy plan that assesses state generation resources and establishes 
broad policy goals. ${ }^{13}$ More recently, a variety of states have been developing energy assurance plans or broader resilience plans to mitigate the impacts of disasters. ${ }^{14}$ This includes 12 states that have pursued energy assurance planning to provide secure and reliable energy infrastructure in the face of natural or human-caused disasters. ${ }^{15}$ Resiliency planning achieves similar outcomes, though it incorporates more threats, vulnerabilities, and mitigation strategies than those tailored specifically to the energy sector. ${ }^{16}$ Updating energy assurance or resilience plans to include microgrids can achieve several objectives. From energy planning, policymakers can understand the reliability benefits resilient microgrids might offer to a state's energy infrastructure portfolio. From resiliency and energy assurance planning, decisionmakers can identify the key threats to their critical infrastructure and whether a microgrid might be an appropriate resilience solution. These efforts can also signal state interest in microgrids, potentially attracting private investment in the state.

Another essential step is establishing a framework that identifies and quantifies microgrid value streams as microgrid stakeholders have indicated that this represents a key barrier to deployment (DNV GL 2015). The inability to monetize certain value streams, like resilience, can make it difficult for microgrid developers to demonstrate attractive payback periods to end users. ${ }^{17}$ Interviewees suggested that policymakers might consider establishing cost benefit analysis frameworks that can be used to quantify the value streams for microgrids, as well as the costs. ${ }^{18}$ This can provide frameworks for understanding which projects might most cost-effectively achieve a state's resiliency goals. The New York State Energy Research and Development Authority's Cost Benefit Analysis model used in the NY Prize program offers one example for valuing microgrid benefits including resilience (NYSERDA 2018). This tool allows project developers, and other stakeholders to compare the costs and benefits of a project under different outage scenarios. In addition, microgrid projects can be compared across geographies and designs against one single benefit/cost metric. A key ongoing challenge in New York, and other states, is how to ensure microgrids are compensated for the resilience value they offer to the electrical grid. ${ }^{19}$ States might consider developing their own cost/benefit framework that incorporates resilience and other value streams to address this market barrier.

Even if a project's benefits outweigh costs, the regulatory treatment of microgrid project developers as well as their access to rights-of-way can influence developer interest. In some states it is unclear whether microgrid developers will be regulated as electric utilities or be exempt. ${ }^{20}$ If microgrid developers are subject to the same regulatory requirements as utilities, it could result in significant regulatory burdens that may discourage private investment. Electric

\footnotetext{
${ }^{13}$ For a listing of all the states with energy plans see: http://www.naseo.org/state-energy-plans.

${ }^{14}$ For more information on resiliency planning see: https://www.nrel.gov/tech deployment/resilience-planningroadmap/

${ }^{15}$ For a listing of states that have adopted state energy assurance plans see: http://www.naseo.org/ea-state-updates.

${ }^{16}$ For example, community resilience planning may incorporate economic sectors, emotional resilience, and other sectors that are beyond the specific focus of energy sector resilience. For examples, of community-based resiliency planning see: http://www.coresiliency.com/developing-a-resiliency-framework.

${ }^{17}$ Market structure can also influence which value streams may be available to a microgrid developer.

${ }^{18}$ A state might also consider clarifying or establishing rate structures for system owners that compensate for the benefits and services provided by the microgrid (McLaren 2015).

${ }^{19}$ States might also consider the cost benefit methodology articulated in Laws et al. 2018.

20 This challenge is related to Level 3 microgrids, where a developer may work with multiple customers.
} 
utilities are also often the only entities that can build infrastructure that crosses public streets or rights-of-way. ${ }^{21}$ Interviewees asserted this is another key challenge, given the uncertainty that project developers will be able to install microgrid infrastructure. To address this pair of concerns, states may wish to take the approach of Connecticut and exclude certain microgrid projects and their developers from the definition of an electric utility, while granting them access to rights-of-way.

Along with these regulatory challenges, interconnection barriers have also been cited as a challenge for microgrid deployment by interviewees and the literature (Bower 2014; DNV GL 2015; McLaren 2015). The Institute of Electrical and Electronics Engineers (IEEE) sets standards for the electricity sector, and IEEE 1547 is a common industry standard for integrating distributed energy resources to the grid, including microgrids. ${ }^{22}$ Until 2018, this standard did not offer specific guidance on certain microgrid challenges, including specifications for intentional islanding. The lack of uniform or consistent interconnection standards for microgrids can make receiving utility approval resource intensive. Policymakers may wish to consider evaluating how their interconnection standards address microgrids, especially given IEEE adopted new standards in 2018 (IEEE 2018). ${ }^{23}$

\subsection{Market Creation}

Once market preparation policies are in place, market creation policies can further initiate public support for microgrid development. Although policymakers could consider a range of policy options for market creation, this report describes three pathways that have been used for microgrid deployment specifically, or clean energy more broadly, including: pilots, utility procurement, and mandates. These policies are laid out from lowest impact to highest in terms of establishing a market.

Pilots or demonstration projects by design are lower-impact initiatives to evaluate the benefits of certain technologies or ideas and generate a set of lessons learned. Pilot projects can then be used as a foundation to scale programs. As noted in Section 3, a variety of states offer some example resilient microgrid programs that could be adopted as pilots in other states. The phased funding programs for microgrid deployment employed in Massachusetts, New Jersey, and New York may be attractive to some policymakers to identify market interest and project viability (Celtic Energy 2017). In comparison, the direct funding approach for specified projects, used in the case of California, Connecticut, New Jersey, Vermont, and Washington could be of interest to those states that might have already identified high priority resilient microgrid projects. ${ }^{24}$

States might also consider adopting utility procurement programs to support a resilient microgrid market. This approach may be most applicable in states with fully regulated electricity markets,

\footnotetext{
${ }^{21}$ In some states, microgrid developers may also face a challenge when attempting to sell retail power to customers, especially outside the 15 deregulated states (Flores-Espino et al. 2016).

${ }^{22}$ For more information on this standard see: http://ieeexplore.ieee.org/document/7356267/.

${ }^{23}$ States may also wish to review IEEE 2030.7-2017 that establishes new standards for microgrid controllers to increase standardization and interoperability of microgrid energy management systems, microgrid components, and distributed energy resources. For more information on the standards see:

https://standards.ieee.org/findstds/standard/2030.7-2017.html.

${ }^{24}$ States might also consider adopting elements of each approach to tailor pilot programs to their unique context.
} 
where utilities are often the sole provider of electricity to end-users. ${ }^{25}$ In this context, regulators could encourage utilities to propose procuring resilient microgrids by clarifying that these projects align with the public interest (Maryland Energy Administration 2014). ${ }^{26}$ Some regulators have already approved microgrid projects that might serve as models for other states. In 2012, ratepayer funds were used to support a microgrid project between San Diego Gas \& Electric and the City of San Diego in California (Smart City San Diego 2012; Gonzales, AliagaCaro, and Klauer 2017). Illinois regulators have also approved microgrid projects for both Ameren Corporation and Commonwealth Edison Company (Wood 2017b; Begos 2018). Interviewees noted that the key challenges for deploying more microgrids via this pathway stem from regulatory uncertainty relating to the distribution of microgrid costs among participants and/or ratepayers and the ownership structure of the microgrid. The distribution of these costs may depend in part on how resilience benefits of a microgrid are valued and spread across relevant participants and ratepayers. These questions will have to be resolved on a state-by-state basis or regionally through independent system operator or regional transmission organization proceedings before the utility procurement pathway will foster broad deployment.

Instead of allowing utilities to voluntarily propose microgrid projects, policymakers could also consider mandating deployment. Though there are no state policies of this type, there are examples in other clean energy contexts. For example, 29 states and the District of Columbia have renewable portfolio standards (RPS) that require a certain percentage of electricity generation come from renewable sources, such as PV and wind (Barbose 2017). Eighteen states and the District of Columbia also have distributed generation "carve outs" in their renewable portfolio standard programs, while four (California, Massachusetts, New York, and Oregon) have separate energy storage mandates (Barbose 2017; Maloney 2017; Spector 2017). States could consider how the combination of renewable energy, energy efficiency, and energy storage in microgrids might help them support these renewable energy goals while also achieving their resiliency objectives. Policymakers could also consider integrating microgrids into existing mandates or establishing stand-alone resilient microgrid targets. ${ }^{27}$ Policymakers should consider a wide variety of issues before establishing future mandates to ensure the program(s) achieves objectives cost effectively. Nevertheless, mandates could be used to create a more robust market for resilient microgrids.

\subsection{Market Expansion}

Once markets are established, there are a variety of policies states could adopt to expand private sector interest in resilient microgrids. Policies could expand financing to microgrid developers, research and development in new business models and technology innovation, or reform energy markets. A few states have adopted some of these approaches for resilient microgrids, while others have not yet been used for this purpose.

\footnotetext{
${ }^{25}$ For the 15 states with deregulated markets, utilities may face more challenges in constructing microgrids, or be prohibited. For more information on electricity market regulation see Flores-Espino et al. (2016).

${ }^{26}$ In October 2017, Pepco proposed two resilient microgrids for approval to the Maryland Public Service Commission (Wood 2017a).

${ }^{27}$ Another option would be for the state to require certain critical infrastructure sectors to adopt back up generation or islanding capabilities as a pathway to support resilient microgrids.
} 
States can play a critical role in supporting private sector investment by offering financing terms otherwise unavailable in the market in the form of public private partnerships. Five states have established "green banks" that are public or quasi-public lending institutions designed to support clean energy and infrastructure projects. ${ }^{28}$ These institutions often work with private lenders to supplement private capital or reduce lending risk. Green banks in Connecticut and New York have explicitly committed to supporting microgrid deployment (NYSERDA 2017; CT Green Bank 2017). Connecticut's Green Bank offers a standalone microgrid funding program that will offer loans up to $\$ 2$ million over a 20 -year term with interest rates between $3 \%$ and $7 \%$. New Jersey has also established an energy resiliency bank capitalized with $\$ 200$ million in federal grants to support the deployment of distributed energy resources at critical infrastructure. ${ }^{29}$ These types of programs can be helpful for supporting state microgrid deployment goals, especially in those cases where private investment may be lacking. These platforms can also serve as a foundation for fostering broader dialogue between developers, financiers, and utilities to identify and finance additional microgrid projects.

Interviewees suggested that states could also adopt a variety of novel financing options to support deployment, including tax exemptions for microgrid projects, incorporating microgrids into energy savings performance contracting (ESPC) programs, or allowing microgrids as eligible projects in tax increment financing (TIF) or energy improvement districts. There are a variety of tax incentives states could consider, such as property or sales tax exemptions for microgrid equipment. These exemptions could reduce overall project costs by allowing project developers or partners to reduce their tax obligations as has been done to support renewable projects nationwide. ${ }^{30}$ An ESPC allows certain property owners to enter into agreements with energy service companies to build renewable energy or energy efficiency projects at no upfront cost to the property owner. Then, the property owner receives guaranteed savings over the life of the contract. Many states have ESPC programs, and it is possible that microgrid projects could be incorporated as eligible projects, thereby reducing upfront capital costs. ${ }^{31}$ TIF districts are designated locations, typically within a municipality where eligible property owners can qualify for tax-related financing. The property owner can receive a loan from a municipality, and that loan may be reimbursed through increased property value associated with the district. One example is the City of Chicago's Small Business Improvement Fund that provides TIF revenues for certain clean energy projects, including PV. ${ }^{32}$ These districts can also be paired with energy improvement districts, where property owners can pursue joint energy projects to reduce costs. For example, Connecticut allows municipalities to designate energy improvement districts and include microgrids as a potential project. ${ }^{33}$ These financing enhancements may support more widespread deployment, but they may not be applicable for all resilient microgrid configurations.

\footnotetext{
${ }^{28}$ For more information on green banks see: http://coalitionforgreencapital.com/whats-a-green-bank-html/.

${ }^{29}$ The bank is currently reviewing applications and expects to exhaust its funds on already submitted projects. For more information on this program see: http://www.njeda.com/erb/erb-(1).

${ }^{30}$ For examples of tax incentives for other clean energy technologies see: http:/www.dsireusa.org/.

${ }^{31}$ For a listing of states with ESPC programs see: https://spotforcleanenergy.org/policy/energy-savingsperformance-contracting/.

${ }^{32}$ For more information on this program see: http://somercor.com/sbif/.

${ }^{33}$ For more information on this program see: $\mathrm{https}$ ://www.cga.ct.gov/2013/act/pa/pdf/2013PA-00298-R00HB06360-PA.pdf.
} 
Therefore, policymakers may wish to consider the types of microgrids they are most interested in supporting and design financial incentives accordingly.

Policymakers could also pursue research and development efforts targeted at microgrid technology innovation and business development. The declining costs of renewable energy are correlated with targeted public investments in research and development (SETO 2017). It is possible that similar efforts to support microgrid control and islanding technology could also spur lower cost projects. Targeted investments in identifying viable business models that monetize microgrid services could also foster more private sector investment in this market. Six states have adopted clean energy centers or technology incubators to support start-ups, commercialize technologies, and provide business support services (Cook 2017). For example, the Massachusetts Department of Energy Resources in partnership with the Massachusetts Clean Energy Center has awarded $\$ 20$ million to 26 energy storage projects that focus specifically on identifying innovative business models and value streams for this technology. ${ }^{34}$ Similar statedriven efforts could be used to help support the development of new revenue streams relating to microgrids such as designing markets for transactive energy between participating customers. Successful research, development, and commercialization activities associated with microgrids, could result in a broader market than what exists today.

Policymakers might also consider proceedings to evaluate how state energy markets are structured and how emerging energy technologies and services, like microgrids, may be used to serve policy goals. Four aforementioned states have taken steps to evaluate new energy market and regulatory models, including Hawaii, Illinois, New York, and Rhode Island. These efforts to envision and implement a more holistic approach to energy markets can help a state consider how microgrids can serve state energy policy goals, while also accounting for how policy changes may influence other components of the market. For example, a key goal behind Rhode Island's effort is to offer customers more energy choices and improve resilience (Division of Public Utilities and Carriers, Office of Energy Resources, and Public Utilities Commission, 2017). The resulting regulatory structure could be designed to include market or financing pathways to enable additional resilient microgrids to support this goal. Other states could take a similar comprehensive approach to integrate resilient microgrid objectives within broader energy market goals to ensure initiatives are not implemented at cross purposes.

\footnotetext{
${ }^{34}$ For more information on this program see: https://www.mass.gov/service-details/esi-demonstration-programadvancing-commonwealth-energy-storage-esi-aces.
} 


\section{Conclusion}

Natural disasters have demonstrated the dependence critical infrastructure has on the electrical grid. This report explores this interdependency and the possible implications of grid outages at critical facilities. In short, there are millions of critical facilities across the country and grid outages may result in significant economic damages as well as negative societal impacts. Resilient microgrids that incorporate renewable energy and battery storage are one pathway to reduce the risk of outages at critical infrastructure. A small subset of states has subsequently adopted microgrid-related policies, but the overall lack of supportive policy has been cited as a key barrier to market growth.

To support policymakers interested in building a more robust resilient microgrid market, this report constructs a policy stack. The stack sequences policy from market preparation through market expansion to help policymakers understand what types of policies are foundational to a market versus those that might create or expand a market. This framework and related policies may be helpful for states that are just beginning to consider the role resilient microgrids might play in achieving their broader resilience and energy priorities.

Though this work offers some noteworthy findings, more research is necessary to help inform policymaker decisions regarding critical infrastructure resilience. First, defining and tracking critical infrastructure will be a challenging, but important step for policymakers to begin prioritizing facilities for resiliency solutions. Officials may also benefit from related research focused on developing a set of criteria to differentiate facilities that might be considered "critical" along with each of those facilities" "critical load." The set of prioritization criteria could include an assessment of estimated outage impacts, services impacted, critical load, and lives disrupted. Developing this set of criteria will help policymakers make decisions with limited resources while documenting how much facility load is critical to providing essential services. Second, the policy stack developed in this report is based on the perspectives of interviewees and existing literature. Though these individuals provide a useful primary perspective on the key policies necessary to support a market, more quantitative analysis of how these policies work together and influence deployment would be valuable. This analysis would also help clarify which policies may be most important for supporting a robust market, thereby helping states prioritize some over others. Third, as states gain more experience with microgrid technology, policies may evolve, which will warrant subsequent analysis to re-design or build out a more comprehensive policy stack. In summary, this work should serve as an important first step in a broader research agenda focused on improving critical infrastructure resilience nationwide. 


\section{References}

Acree, Keith. 2018. Assessments aim to increase resilience of critical infrastructure serving Outer Banks. https://www.ncdps.gov/news/press-releases/2018/05/21/assessments-aim-increaseresiliency-critical-infrastructure-serving.

Allen, Greg. 2017. "Puerto Rico Hospitals are Struggling to Provide Care After Hurricane Maria.” National Public Radio. https://www.npr.org/2017/09/27/554057358/puerto-ricohospitals-are-struggling-to-provide-care-after-hurricane-maria.

Anderson, Kate, Nick DiOrio, Dylan Cutler, Bob Butt, and Allison Richards. 2017. "Increasing Resiliency Through Microgrids.” Journal of Energy Management 2(2).

https://www.nrel.gov/docs/fy17osti/69034.pdf.

APTA (American Public Transportation Association). 2015. 2015 Public Transportation Fact Book. http://www.apta.com/resources/statistics/Documents/FactBook/2015-APTA-FactBook.pdf.

Asiedu-Saforo, Kwame. "Economic reform programmes and agricultural development: Macro policy sequencing in Ghana, 1983-1988." Food policy 14, no. 4 (1989): 359-370.

Barbose, Galen. 2017. U.S. Renewables Portfolio Standards 2017 Annual Status Report. https://emp.lbl.gov/sites/default/files/2017-annual-rps-summary-report.pdf.

Begos, Kevin. 2018. "Illinois case could help other utilities seeking to fund microgrids." Energy News Network. https://energynews.us/northeast/illinois-case-could-help-other-utilities-seekingto-fund-microgrids/.

Bower, Ward, Dan Ton, Ross Guttromson, Steve Glover, Jason Stamp, Dhruv Bhatnagar, and Jim Reilly. 2014. The Advanced Microgrid Integration and Interoperability. Albuquerque, NM: Sandia National Laboratories. SAND2014-1535. http://prod.sandia.gov/techlib/accesscontrol.cgi/2014/141535.pdf.

Celtic Energy. 2017. Resilient Microgrids for Rhode Island Critical Services. http://www.energy.ri.gov/documents/SRP/RI-microgrid-exec-summary-170331.pdf.

City of Philadelphia. 2014. City of Philadelphia Energy Benchmarking Report. http:/www.phillybuildingbenchmarking.com/wpcontent/uploads/2015/09/MOS_BnchMrkRprt_R5fin_FINAL.pdf.

CMS (Centers for Medicare and Medicaid Services). 2017. 17 Facility-Provider Supplier Types Impacted. https://www.cms.gov/Medicare/Provider-Enrollment-and-

Certification/SurveyCertEmergPrep/Downloads/17-Facility-Provider-Supplier-TypesImpacted.pdf.

Cook, Jeffrey J. 2017. Clean Energy-Related Economic Development Policy across the States: Establishing a 2016 Baseline. Golden, CO: National Renewable Energy Laboratory. NREL/TP6A20-67656. http://www.nrel.gov/docs/fy17osti/67656.pdf. 
CT Green Bank (Connecticut Green Bank). 2017. Connecticut Green Bank Microgrid Financing Program. https://www.ctgreenbank.com/microgrids/.

Daugbjerg, Carsten. "Sequencing in public policy: the evolution of the CAP over a decade." Journal of European Public Policy 16, no. 3 (2009): 395-411.

Demont, Matty, and Amy C. Rizzotto. "Policy sequencing and the development of rice value chains in Senegal." Development Policy Review 30, no. 4 (2012): 451-472.

DNV GL. 2015. Microgrid Assessment and Recommendation(s) to Guide Future Investments. http://www.energy.ca.gov/2015publications/CEC-500-2015-071/CEC-500-2015-071.pdf.

Division of Public Utilities and Carriers, Office of Energy Resources, and Public Utilities Commission. 2017. Rhode Island Power Sector Transformation Phase One Report to Governor Gina M. Raimondo. http://www.ripuc.org/utilityinfo/electric/PST\%20Report_Nov 8.pdf.

DOE (U.S. Department of Energy). 2012. The U.S. Department of Energy's Microgrid Initiative. https://www.energy.gov/sites/prod/files/2016/06/f32/The\%20US\%20Department $\% 20$ of\%20Ener gy $\% 27 \mathrm{~s} \% 20$ Microgrid $\% 20$ Initiative.pdf.

EIA (Energy Information Administration). 2018. "In 2017, U.S. electricity sales fell by the greatest amount since the recession." Today In Energy.

https://www.eia.gov/todayinenergy/detail.php?id=35612.

EIA (Energy Information Administration). 2015a. Number and Capacity of Petroleum Refineries. https://www.eia.gov/dnav/pet/pet_pnp_cap1_dcu_nus_a.htm.

EIA (Energy Information Administration). 2015b. Fuel Consumed at Refineries. https://www.eia.gov/dnav/pet/pet_pnp_capfuel_dcu_nus_a.htm.

EIA(Energy Information Administration). 2006. 2003 CBECS Survey Data. Microdata. http://www.eia.gov/consumption/commercial/data/2003/index.cfm?view=microdata.

EPRI (Electric Power Research Institute). 2013. Electricity Use and Management in the Municipal Water Supply and Wastewater Industries.

http://www.epri.com/abstracts/Pages/ProductAbstract.aspx?ProductId=000000003002001433.

Energy Star. 2016. U.S. Energy Use Intensity by Property Type.

https://portfoliomanager.energystar.gov/pdf/reference/US\%20National\%20Median\%20Table.pdf

Executive Office of the President. 2013. Economic Benefits of Increasing Electric Grid Resilience to Weather Outages.

https://www.energy.gov/sites/prod/files/2013/08/f2/Grid\%20Resiliency\%20Report_FINAL.pdf.

FEMA (Federal Emergency Management Agency). 2018. Hurricane Maria.

https://www.fema.gov/hurricane-maria. 
Flores- Espino, Francisco, Tian Tian, Ilya Chernyakhovskiy, Megan Mercer, and Mackay Miller. 2016. Competitive Electricity Market Regulation in the United States: A Primer. National Renewable Energy Laboratory. Golden, CO. https://www.nrel.gov/docs/fy17osti/67106.pdf.

Fu, Ran, David Feldman, Robert Margolis, Mike Woodhouse, and Kristen Ardani. 2017. U.S. Solar Photovoltaics System Cost Benchmark: Q1 2017. Golden, CO: National Renewable Energy Laboratory. NREL/TP-6A20-68925. https://www.nrel.gov/docs/fy17osti/68925.pdf.

Gonzales, Rey, Jose Aliaga-Caro, Peter Klauer. 2017. A Roadmap for Commercializing Microgrids in California. http://docketpublic.energy.ca.gov/PublicDocuments/16-EPIC01/TN220364_20170725T151033_A_Roadmap_for_Commercializing_Microgrids_in_Californi a.pdf.

Hotchkiss, Eliza, Ian Metzger, James Salasovich, and Paul Schwabe. 2013. Alternative Energy Generation Opportunities in Critical Infrastructure New Jersey. National Renewable Energy Laboratory. NREL/TP-7A40-60631. https://www.nrel.gov/docs/fy14osti/60631.pdf.

Hotchkiss, Eliza, Alexander Dane, and Connie Komomua. 2016. Resilience Roadmap: A Collaborative Approach to Multi-Jurisdictional Planning. National Renewable Energy Laboratory. https://www.nrel.gov/resilience-planning-roadmap/.

IEEE 2018. IEEE Standard for Interconnection and Interoperability of Distributed Energy Resources with Associated Electric Power Systems Interfaces. https://ieeexplore.ieee.org/stamp/stamp.jsp?tp=\&arnumber=8332112\&tag=1.

Krasko, Vitaliy A. and Elizabeth Doris. 2013. "State distributed PV policies: Can low cost (to government) policies have a market impact?” Energy Policy (59); pp. 172-181.

Kusisto, Laura, and Arian Campo-Flores. 2017. "Homes Built to Stricter Standards Fared Better in Storm." The Wall Street Journal. https://www.wsj.com/articles/one-early-lesson-from-irmahurricane-building-codes-work-1505559600.

Ladnier, Patrica. 2017. Critical Infrastructure and Federal Statutory Authority for the Departments of Homeland Security and Defense to Perform Two Key Tasks. http://www.dtic.mil/dtic/tr/fulltext/u2/1039175.pdf.

Larsen, Peter A., Brent Boehlert, Joseph H. Eto, Kristina Hamachi-LaCommare, Jeremy Martinich, and Lisa Rennels. 2017. Projecting Future Costs to U.S. Electric Utility Customers from Power Interruptions. Berkeley, CA: Lawrence Berkeley National Laboratory. LBNL1007027.

Laws, Nicholas D., Kate Anderson, Nicholas A. DiOrio, Xiangkun Li, and Joyce McLaren. 2018. "Impacts of Valuing Resilience on Cost-Optimal PV and Storage Systems for Commercial Buildings.” https://www.cleanegroup.org/wp-content/uploads/Valuing-Resilience.pdf.

Maloney, Peter. 2017. "California PUC finalizes new 500 MW BTM battery storage mandate.” Utility Dive. https://www.utilitydive.com/news/california-puc-finalizes-new-500-mw-btmbattery-storage-mandate/441901/. 
Maryland Energy Administration. 2014. Maryland Resiliency Through Microgrids Task Force Report.

http://energy.maryland.gov/Documents/MarylandResiliencyThroughMicrogridsTaskForceReport 000.pdf.

McLaren, Joyce. 2015. Distributed Solar PV for Electricity System Resiliency Policy and Regulatory Considerations. National Renewable Energy Laboratory. Golden, CO.

https://www.nrel.gov/docs/fy15osti/62631.pdf.

Meckling, Jonas, Thomas Sterner, and Gernot Wagner. "Policy sequencing toward decarbonization." Nature Energy 2, no. 12 (2017): 918.

Medicare and Medicaid Programs; Emergency Preparedness Requirements for Medicare and Medicaid Participating Providers and Suppliers; Final Rule 2016, 81 Fed.Reg. 63860 (September 16, 2016) (to be codified at 42 CFR Parts 403, 416, 418, et al.).

Melkunaite, Laura, Marwan Alheib, G. Baker, Gonçalo Rodrigues Cadete, Elisabete Carreira, Kerstin Eriksson, C. Gaspar, Peter Gattinesi, Fanny Guay, Dániel Honfi, Ioannis Ioannou, Jannes Kinscher, David Lange, Laura Petersen, Paul J. Reilly, Bjarte Rod, Romuald Salmon, R. Stevenson, Marianthi Theocharidou, Andrei Utkin. 2016. Improved Risk Evaluation and Implementation of Resilience Concepts to critical Infrastructure.

http://www.risefr.no/media/publikasjoner/upload/2016/d1-120international20survey.pdf.

Metelitsa, Colleen. 2017. U.S. Microgrids 2017: Market Drivers, Analysis and Forecast. GTM Research. https://www.greentechmedia.com/research/report/us-microgrids-2017\#gs.YrT tck.

Moteff, John and Paul Parfomak. 2004. Critical Infrastructure and Key Assets: Definition and Identification. Congressional Research Service. https://fas.org/sgp/crs/RL32631.pdf.

Murck, Jeanne Murphy. 2016. "Critical Operations Power Systems.” Core Engineered Solutions. http://core-es.com/critical-operations-power-systems.

Nehamas, Nicholas. and Elizabeth Koh. 2018. "After 12 elders died, nursing homes get generators. But when will they be inspected?" Miami Herald. http://www.miamiherald.com/news/local/community/broward/article207572489.html.

New Jersey BPU (Board of Public Utilities). 2016. Microgrid Report. http://www.nj.gov/bpu/pdf/reports/20161130_microgrid_report.pdf.

NOAA (National Oceanic and Atmospheric Administration). 2018a. Billion-Dollar Weather and Climate Disasters: Overview. https://www.ncdc.noaa.gov/billions/.

NOAA. 2018b. Billion-Dollar Disasters: Calculating the Costs. https://www.ncdc.noaa.gov/monitoring-references/dyk/billions-calculations.

NRDC (Natural Resources Defense Council). 2014. Issue Paper: Data Center Efficiency Assessment Scaling up Energy Efficiency Across the Data Center Industry: Evaluating Key 
Drivers and Barriers. https://www.nrdc.org/sites/default/files/data-center-efficiency-assessmentIP.pdf.

Nsouli, Saleh M., Mounir Rached, and Norbert Funke. "The speed of adjustment and the sequencing of economic reforms: Issues and guidelines for policymakers." International Journal of Social Economics 32, no. 9 (2005): 740-766.

NYSERDA (New York State Energy Research and Development Authority). 2018. Resources for Applicants. https://www.nyserda.ny.gov/All-Programs/Programs/NY-Prize/Resources-forapplicants.

NYSERDA. 2017. Governor Cuomo Announces \$11 Million Awarded for Community Microgrid Development Across New York. https://www.nyserda.ny.gov/About/Newsroom/2017-

Announcements/2017-03-23-Governor-Cuomo-Announces-11-Million-Awarded-forCommunity-Microgrid-Development.

OECD (Organisation of Economic Cooperation and Development). 2008. Protection of 'Critical Infrastructure' and the Role of Investment Policies Relating to National Security. https://www.oecd.org/daf/inv/investment-policy/40700392.pdf.

Office of Electricity. 2018. Microgrid Portfolio of Activities. https://www.energy.gov/oe/services/technology-development/smart-grid/role-microgridshelping-advance-nation-s-energy-syst-0.

Ostroff, Caitlin. 2017. "Rehabilitation Center at Hollywood Hills cited for building violations." Miami Herald. http://www.miamiherald.com/news/local/community/broward/article175766806.html.

Parise, Giuseppe. Luigi Parise, Luigi Martirano, Peniamin Ben Chavdarian, Chun-Lien Su, and Andrea Ferrante. 2016. Wise Port and Business Energy Management: Port Facilities, Electrical Power Distribution. IEEE Transactions on Industry Applications 52(1). http://ieeexplore.ieee.org/stamp/stamp.jsp?arnumber=7167710.

Popescu, Cristian-Aurelian and Cristina Petronela Simion. 2012. "A method for defining critical infrastructures." Energy 42(1): (32-34). https://www.sciencedirect.com/science/article/pii/S0360544211006220\#bib4.

Rezkallah, Miloud, Ambrish Chandra, Bihm Singh, and Sanjeev Singh. 2017. "Microgrid: Configurations, Control and Applications." IEEE Transactions on Smart Grid. https://ieeexplore.ieee.org/stamp/stamp.jsp?tp=\&arnumber=8066372.

Riedman, David. 2016. "Questioning the Criticality of Critical Infrastructure: A Case Study Analysis. Homeland Security Affairs. https://www.hsaj.org/articles/10578.

Saadeh, Omar. 2016. U.S. Microgrids 2016: Market Drivers, Analysis and Forecast. GTM Research. https://www.greentechmedia.com/research/report/us-microgrids-2016. 
San Francisco Police. 2012. Climate Action Plan.

https://sfenvironment.org/sites/default/files/fliers/files/sfpd cap fy1011 2012 0413.pdf.

SDG\&E (San Diego Gas \& Electric). 2015. Exhibits (Public Version) San Diego Gas \& Electric Company Comments to the Recirculated DEIR. http://www.cpuc.ca.gov/Environment/info/ene/socre/attachment/3\%20\%20PUBLIC\%20Exhibits_SDGE\%20Comments\%20on\%20Recirculated\%20DEIR.pdf.

Secretary of the Army. 2017. SUBJECT: Army Directive 2017-07 (Installation Energy and Water Security Policy). http://www.asaie.army.mil/Public/ES/doc/Army_Directive_2017-07.pdf.

SETO (Solar Energy Technology Office). 2017. 2020 Utility-Scale Solar Goal Achieved. https://www.energy.gov/eere/solar/articles/2020-utility-scale-solar-goal-achieved.

Smart City San Diego. 2012. Smart City San Diego \& San Diego Zoo Unveil Solar To Electric Vehicle Charging Project. Press Release. https://www.prnewswire.com/news-releases/smartcity-san-diego--san-diego-zoo-unveil-solar-to-electric-vehicle-charging-project-168644186.html.

Soyibo, Adedoyin. "Financial liberalisation and bank restructuring in sub-saharan Africa: some lessons for sequencing and policy design." Journal of African Economies6, no. 1 (1997): 100150.

Spector, Julian. 2017. "New York Governor Approves Energy Storage Target, Months After the Bill Passed." Greentech Media. https://www.greentechmedia.com/articles/read/new-yorkapproves-energy-storage-target\#gs.I3bEvG8.

Spooner, Neil J., and Lawrence D. Smith. Structural adjustment policy sequencing in SubSaharan Africa. No. 104. Food \& Agriculture Org., 1991.

Steward, Darlene, Elizabeth Doris, Vitaly Krasko, and Daniel Hillman. 2014. The Effectiveness of State-level Polices on Solar Market Development in Different State Contexts. Technical Report NREL/TP-7A40-61029. National Renewable Energy Laboratory: Golden, Colorado. https://www.nrel.gov/docs/fy14osti/61029.pdf.

Steward Darlene, and Elizabeth Doris. 2014. The Effect of State Policy Suites on the Development of Solar Markets. NREL/TP- 7A40-62506. National Renewable Energy Laboratory: Golden, CO. https://www.nrel.gov/docs/fy15osti/62506.pdf.

Sullivan, Michael J., Josh Schellenberg, and Marshall Blundell. 2015. Updated Value of Service Reliability Estimates for Electric Utility Customers in the United States. Ernest Orland Lawrence Berkeley National Laboratory. LBNL-6941E. https://emp.lbl.gov/sites/default/files/lbnl6941e.pdf.

Thomas, Jeremy. 2017. LLNL project aims to transform electrical grid resiliency with distributed energy resources. https://www.llnl.gov/news/llnl-project-aims-transform-electricalgrid-resiliency-distributed-energy-resources. 
Urban Environmental Research LLC. 2008. Clark County: Critical Infrastructure \& Key Assets Final-May 19, 2008. http://www.clarkcountynv.gov/comprehensive-planning/regulatedbusiness/Documents/Studies/CCCriticalInfrastructure0508.pdf.

Wood, Elisa. 2017a. "Maryland Utility Proposes \$44.2M Pilot for Public Purpose Microgrids." Microgrid Knowledge. https://microgridknowledge.com/public-purpose-microgrids-pepco/.

Wood, Elisa. 2017b. "Microgrid Islanding: S\&C and Ameren Show it Works at Illinois Microgrid." Microgrid Knowledge. https://microgridknowledge.com/microgrid-islandingameren/.

World Bank. Country Policy Department, and Michael Michaely. The timing and sequencing of a trade liberalization policy. World Bank, Country Policy Department, 1984. 


\section{Appendix A}

\section{Market Potential Methodology}

This section describes the methodology used to estimate electricity load for certain critical infrastructure as well as the potential economic impact of electricity outages at these facilities.

\section{Critical Infrastructure Load Methodology}

A variety of data sources were selected for generating the aggregate annual load estimates for this assessment. Table 2 includes the key inputs for the electricity load estimate and the following sections describe the data collection process for each subsector.

Table 2. Annual Electricity Load for Certain Critical Infrastructure Subsectors

\begin{tabular}{ll|r|r|r|} 
Sector & Subsector & $\begin{array}{l}\text { Number of Systems } \\
\text { or Facilities }\end{array}$ & $\begin{array}{l}\text { MWh/ } \\
\text { System or } \\
\text { Facility }\end{array}$ & TWh \\
& & 1,362 & 92 & 2.8 \\
\hline Transportation & Other Transit & 15 & 257,000 & 3.9 \\
\hline Transportation & Heavy Rail & 58,750 & 69 & 4.1 \\
\hline Emergency Services & Fire Stations & 12,000 & 6 & 10 \\
\hline Emergency Services & Police Departments & 61 & 106,000 & 13 \\
\hline Transportation & Airports & 114,474 & 151 & 17 \\
\hline Transportation & Gas Stations & 14,769 & 1,900 & 29 \\
\hline Water and Wastewater System & Wastewater & 69,847 & 562,000 & 39 \\
\hline Water and Wastewater Systems & Public Water & 139 & 340,000 & 47 \\
\hline Energy & Oil Refineries & 360 & 176,000 & 64 \\
\hline Transportation & Sea Ports & $14,337,000$ & 5 & 70 \\
\hline Information Technology & Datacenters & 5,600 & 19,000 & 106 \\
\hline Healthcare & Hospitals & 129,000 & 1,271 & 164 \\
\hline Government Services & K-12 Schools & &
\end{tabular}

\section{Energy}

The energy sector includes a variety of power generation facilities as well as infrastructure for refining, storing, and distributing fuel. The EIA tracks electricity consumption across all 139 oil refineries annually, so this consumption was included in this analysis. ${ }^{35}$ The EIA does not track energy consumption associated directly with the other oil and natural gas industries, and the authors could not identify an alternative data source. These and other energy-related sectors were excluded from the market potential estimate.

\section{Government Services}

The government services sector incorporates the consumption data from K-12 schools. These data were sourced from the EIA Commercial Buildings Energy Consumption Survey (CBECS). These CBECS data are presented in Energy Star (2016) that documents the median site energy

${ }^{35}$ Oil refinery fuel consumption is documented here: https://www.eia.gov/dnav/pet/pet_pnp_capfuel_dcu_nus_a.htm and here: https://www.eia.gov/dnav/pet/pet_pnp_capfuel_dcu_nus_a.htm. 
consumption for K-12 schools. Energy Star (2016) offers a median average energy consumption for these facilities in energy consumption per square foot. To generate an aggregate consumption total for each individual school the applicable rate was applied to the median square footage of all schools included in the survey. These facility-level data were then applied to all 129,189 K-12 schools in the country. ${ }^{36}$

\section{Emergency Services}

Fire and police station energy consumption are the only two emergency service sectors included in this analysis. Fire and police stations are tracked in one combined category in CBECS. This is problematic because the load associated with these two sectors is significantly different (see City of Philadelphia 2014). This analysis generates aggregate load data for each of these sectors based on electricity consumption data identified across a range of police and fire stations. This consumption was then multiplied by the number of facilities nationally including 58,750 fire stations and 12,000 police departments. ${ }^{37}$ Though many police departments may just have one facility, some have multiple, such as San Francisco which has 24 (San Francisco Police 2012). As such, the aggregate load for police departments is likely lower than reflected in this analysis.

\section{Healthcare}

The healthcare sector incorporates the consumption data from hospitals. These data were sourced from the EIA CBECS. These CBECS data are presented in Energy Star (2016) that documents the median site energy consumption for hospitals. Energy Star (2016) offers a median average energy consumption for these facilities in energy consumption per square foot. To generate an aggregate consumption total for each individual hospital the applicable rate was applied to the median square footage of all hospitals included in the survey. These facility-level data were then applied to all 5,627 hospitals in the country. ${ }^{38}$

\section{Information Technology}

The information technology sector includes a variety of products and services including the management and operation of datacenters. Datacenter energy consumption is an important component of this sector and Shehabi et al. 2016 identified more than 14 million datacenters in operation across the United States. Shehabi et al. (2016) estimated datacenter load by facility type and the average rate of consumption for datacenters was included in this analysis.

\section{Transportation}

Most of the electricity consumption data for transportation sector included in this analysis is derived from the American Public Transportation Association's (APTA's) 2015 Public Transportation Fact Book. APTA (2015) tracks the electricity consumption of public transportation systems including buses, rail, and streetcars among others.

Three areas that the APTA does not cover are airports, seaports, and gas stations. Gas station consumption data were sourced from the EIA CBECS. These CBECS data are presented in

\footnotetext{
${ }^{36}$ A listing of all schools in the United States by type is available here: https://nces.ed.gov/fastfacts/display.asp?id=84.

${ }^{37}$ A list of police departments is available here http://www.bjs.gov/index.cfm?ty=tp\&tid=71 and fire stations here:

38 The total number of hospitals in the United States was found here: http://www.aha.org/research/rc/statstudies/fast-facts.shtml.
} 
Energy Star (2016) that documents the median site energy consumption for gas stations. Energy Star (2016) provides the median average energy consumption for these facilities in energy consumption per square foot. To generate an aggregate consumption total for each individual gas station the applicable rate was applied to the median square footage of all stations included in the survey respectively. These facility-level data were then applied to all 114,474 stations in the country. ${ }^{39}$

The authors could not identify a source that comprehensively tracks electricity consumption for either airports or seaports, so an average of publicly available electricity consumption date documented at specific facilities was used. In the case of seaports, the average consumption generated from this search was applied to all 360 ports in the United States. Given there are more than 5,000 public airports with significant variation in size, the average electricity consumption generated for airports was applied to only those airports designated as large or medium hubs (61 airports) by the Federal Aviation Administration. ${ }^{40}$ This was done because the demand estimates included in this analysis were associated with large or medium hubs.

\section{Water and Wastewater Treatment}

EPRI (2013) documents the electricity consumption associated with certain public water and wastewater treatment systems and the quantity of public water $(69,847)$ and wastewater treatment $(14,769)$ plants that employ each treatment system. As a result, the consumption data employed in this analysis account for the variation in treatment system used.

\section{Economic Impact of Outage Methodology}

With the aforementioned load data by facility it was possible to apply the estimated economic impact rate from the ICE model for a four and 16-hour outage. The cost of these outages by sector are documented in Table 3. Simply stated, those facilities with average load greater than $50 \mathrm{MWh}$ were considered to face the same economic loss as large commercial and industrial customers. In comparison, those facilities with average load fewer than $50 \mathrm{MWh}$ were considered to face economic losses similar to small commercial customers and thus the lower rate was applied.

\footnotetext{
${ }^{39}$ The total number of gas stations was derived from the 2012 census and is available here: http:/factfinder.census.gov/faces/tableservices/jsf/pages/productview.xhtml?pid=ECN_2012_US_44SSSZ1\&prodT ype $=$ table.

40 This was done because the electricity consumption data identified in this report are related to airports that are all considered large or medium hubs and applying them to all airports would generate a national estimate that is inaccurate. The top 550 airports based on traffic are listed here: http://www.faa.gov/airports/planning_capacity/passenger_allcargo_stats/passenger/media/cy14-commercial-serviceenplanements.pdf.
} 
Table 3. Estimated Outage Cost by Critical Infrastructure Subsector System or Facility

\begin{tabular}{|c|c|c|c|c|c|c|}
\hline Sector & Subsector & $\begin{array}{l}\text { Number of } \\
\text { Systems or } \\
\text { Facilities }\end{array}$ & $\begin{array}{l}\text { Cost/ } \\
\text { Facility } \\
\text { (4-hr } \\
\text { outage) }\end{array}$ & $\begin{array}{l}\text { Cost/ } \\
\text { Facility } \\
\text { (16-hr } \\
\text { outage) }\end{array}$ & $\begin{array}{l}\text { Total Cost } \\
4-\mathrm{hr} \\
\text { outage (in } \\
\text { millions) }\end{array}$ & $\begin{array}{l}\text { Total Cost } \\
16-\mathrm{hr} \\
\text { outage (in } \\
\text { millions) }\end{array}$ \\
\hline Transportation & Other Transit & 1,362 & Varies & Varies & $\$ 5.6$ & $\$ 25$ \\
\hline Transportation & Heavy Rail & 15 & $\$ 39,500$ & $\$ 165,500$ & $\$ 0.5$ & $\$ 2.5$ \\
\hline $\begin{array}{l}\text { Emergency } \\
\text { Services }\end{array}$ & Fire Stations & 58,750 & $\$ 39,500$ & $\$ 165,500$ & $\$ 2,300$ & $\$ 9,600$ \\
\hline $\begin{array}{l}\text { Emergency } \\
\text { Services }\end{array}$ & Police Departments & 12,000 & $\$ 39,500$ & $\$ 165,500$ & $\$ 473$ & $\$ 2,000$ \\
\hline Transportation & Airports & 61 & $\$ 39,500$ & $\$ 165,500$ & $\$ 2.4$ & $\$ 10$ \\
\hline Transportation & Gas Stations & 114,474 & $\$ 39,500$ & $\$ 165,500$ & $\$ 4,500$ & $\$ 18,900$ \\
\hline $\begin{array}{l}\text { Water and } \\
\text { Wastewater } \\
\text { Systems }\end{array}$ & Wastewater & 14,769 & $\$ 39,500$ & $\$ 165,500$ & $\$ 582$ & $\$ 2,400$ \\
\hline $\begin{array}{l}\text { Water and } \\
\text { Wastewater } \\
\text { Systems }\end{array}$ & Public Water & 69,847 & $\$ 39,500$ & $\$ 165,500$ & $\$ 2,800$ & $\$ 11,600$ \\
\hline Energy & Oil Refineries & 139 & $\$ 39,500$ & $\$ 165,500$ & $\$ 5.5$ & $\$ 23$ \\
\hline Transportation & Sea Ports & 360 & $\$ 39,500$ & $\$ 165,500$ & $\$ 14$ & $\$ 60$ \\
\hline $\begin{array}{l}\text { Information } \\
\text { Technology }\end{array}$ & Data Centers & $14,337,000$ & $\$ 1,900$ & $\$ 9,100$ & $\$ 23,100$ & $\$ 111,400$ \\
\hline Healthcare & Hospitals & 5,600 & $\$ 39,500$ & $\$ 165,500$ & $\$ 220$ & $\$ 931$ \\
\hline Education & K-12 Schools & 129,000 & $\$ 39,500$ & $\$ 165,500$ & $\$ 5,100$ & $\$ 21,400$ \\
\hline
\end{tabular}




\section{Appendix B}

Interview questions for state agency representatives:

1. What role does your agency play in regulating microgrids?

a. Do other state agencies have jurisdiction in this policy area?

2. In your view, what have been the key drivers of microgrid deployment in your state?

a. Favorable policy?

b. Industrial processes i.e. university laboratory research?

c. Sector-specific requirements i.e. hospitals?

3. Are you aware of any key challenges or barriers that needed to be resolved to deploy microgrids in your state?

a. If so, can you speak to how they were resolved?

4. What barriers exist to future deployment in your state and how could they be addressed?

5. What future opportunities do you see for microgrids in your state?

a. Any ongoing dockets with a microgrid component?

6. Anything else you would like to add on this topic?

Interview questions for utility representatives:

7. In your opinion what are the main drivers behind increasing microgrid deployment?

8. In general, how many microgrid projects have you worked on?

a. How many of those have included critical infrastructure (hospitals, schools, etc)?

b. How many have incorporated solar and batteries?

9. Does incorporating solar and storage cause unique challenges?

10. What are the top barriers to microgrid deployment?

a. What can state policymakers do to address these barriers?

11. Are there certain state policies or incentives that have been key in fostering microgrid deployment to date? Or, that you would suggest as models for other states?

12. Are there certain state policies that serve as barriers to microgrid deployment to date?

a. How might these be addressed?

13. Can you speak to the outlook for microgrid deployment incorporating solar and storage, or any trends you are seeing in this market?

14. If you operate in different states which markets are easier for microgrids to be deployed in and why? Which states provide more barriers to microgrid deployment?

15. Can you identify third parties (i.e. develpers, government) that are valuable in fostering the future development of microgrids.

16. Anything else you would like to add on this topic?

Interview questions for other microgrid market representatives:

17. In general, how many microgrid projects have you worked on?

a. How many of those have included critical infrastructure (hospitals, schools, etc)?

b. How many have incorporated solar and batteries?

18. Does incorporating solar and storage cause unique challenges? 
19. What are the top barriers to microgrid deployment?

a. What can state policymakers do to address these barriers?

20. Are there certain state policies that have been key in fostering microgrid deployment to date? Or, that you would suggest as models for other states?

21. Are there certain state policies that serve as barriers to microgrid deployment to date?

a. How might these be addressed?

22. Can you speak to the outlook for microgrid deployment incorporating solar and storage, or any trends you are seeing in this market?

23. Are certain states more attractive markets for microgrids and why?

24. Anything else you would like to add on this topic? 


\section{Appendix C}

\section{State Policy Landscape}

Table 4. Identified State Policies and Programs Directly Affecting Microgrid Deployment

\begin{tabular}{|c|c|c|c|c|}
\hline State & Name & Year & Policy Category & Link \\
\hline \multirow{4}{*}{ California } & $\begin{array}{l}\text { California } \\
\text { Microgrid } \\
\text { Roadmap }\end{array}$ & 2017 & Microgrid Roadmap & $\frac{\text { http://www.energy.ca.gov/research }}{\text { /microgrid/ }}$ \\
\hline & $\begin{array}{l}\text { Assembly Bill } \\
1400\end{array}$ & 2017 & $\begin{array}{l}\text { Grants, Loans, and } \\
\text { Other Financing }\end{array}$ & $\begin{array}{l}\underline{\text { http://leginfo.legislature.ca.gov/fac }} \\
\underline{\text { es/billTextClient.xhtml?bill id=2017 }} \\
\underline{\text { 20180AB1400 }}\end{array}$ \\
\hline & $\begin{array}{l}\text { Electric } \\
\text { Program } \\
\text { Investment } \\
\text { Charge } \\
\text { Program } \\
\text { (EPIC) }\end{array}$ & 2016 & $\begin{array}{l}\text { Grants, Loans, and } \\
\text { Other Financing }\end{array}$ & $\begin{array}{l}\text { http://www.energy.ca.gov/contract } \\
\text { s/epic.html } \\
\text { CPUC Decision 12-05-037; Docket } \\
\text { 16-EPIC-01 }\end{array}$ \\
\hline & DNV GL & 2015 & Microgrid Roadmap & $\begin{array}{l}\frac{\text { http://www.energy.ca.gov/2015pub }}{\text { lications/CEC-500-2015-071/CEC- }} \\
\underline{\text { 500-2015-071.pdf }}\end{array}$ \\
\hline \multirow[b]{2}{*}{ Connecticut } & $\begin{array}{l}\text { Public Act 13- } \\
298\end{array}$ & 2013 & Utility Regulation & $\begin{array}{l}\text { https://www.cga.ct.gov/2013/act/p } \\
\text { a/pdf/2013PA-00298-R00HB-06360- } \\
\underline{\text { PA.pdf }}\end{array}$ \\
\hline & $\begin{array}{l}\text { Microgrid } \\
\text { Grant and } \\
\text { Loan } \\
\text { Program }\end{array}$ & 2012 & $\begin{array}{l}\text { Grants, Loans, and } \\
\text { Other Financing }\end{array}$ & $\begin{array}{l}\text { Public Act 12-148, Section } 7 \\
\text { https://www.cga.ct.gov/2012/ACT/P } \\
\text { a/pdf/2012PA-00148-R00SB-00023- } \\
\text { PA.pdf; } \\
\text { http://www.ct.gov/deep/cwp/view. } \\
\text { asp?a=4405\&Q=508780; } \\
\text { http://www.ctgreenbank.com/micro } \\
\text { grids/ }\end{array}$ \\
\hline Hawaii & $\begin{array}{l}\text { House Bill } \\
1700\end{array}$ & 2016 & Microgrid Roadmap & $\begin{array}{l}\text { http://www.capitol.hawaii.gov/sessi } \\
\text { on2016/bills/HB1700 CD1 .htm }\end{array}$ \\
\hline Illinois & $\begin{array}{l}\text { Next Grid } \\
\text { Illinois Utility } \\
\text { of the Future } \\
\text { Study }\end{array}$ & 2017 & $\begin{array}{l}\text { Energy Market } \\
\text { Reform }\end{array}$ & https://nextgrid.illinois.gov/ \\
\hline Maryland & $\begin{array}{l}\text { Resiliency } \\
\text { Through } \\
\text { Microgrids } \\
\text { Task Force }\end{array}$ & 2014 & Microgrid Roadmap & $\begin{array}{l}\text { http://energy.maryland.gov/Pages/r } \\
\text { esiliency.aspx; } \\
\text { http://energy.maryland.gov/Docum } \\
\text { ents/MarylandResiliencyThroughMic } \\
\text { rogridsTaskForceReport 000.pdf }\end{array}$ \\
\hline Massachusetts & $\begin{array}{l}\text { Community } \\
\text { Clean Energy } \\
\text { Resiliency } \\
\text { Initiative }\end{array}$ & 2014 & $\begin{array}{l}\text { Grants, Loans, and } \\
\text { Other Financing }\end{array}$ & $\frac{\text { https://www.mass.gov/service- }}{\underline{\text { details/cceri-program-goals }}}$ \\
\hline
\end{tabular}




\begin{tabular}{|c|c|c|c|c|}
\hline & KEMA & 2014 & Microgrid Roadmap & $\begin{array}{l}\text { http://files.masscec.com/research/ } \\
\text { Microgrids.pdf }\end{array}$ \\
\hline Minnesota & $\begin{array}{l}\text { Microgrid } \\
\text { Institute }\end{array}$ & 2013 & Microgrid Roadmap & $\begin{array}{l}\text { http://mn.gov/commerce- } \\
\text { stat/pdfs/CHP\%20pdfs/MN- } \\
\text { Microgrid-WP-FINAL-amended.pdf }\end{array}$ \\
\hline \multirow[t]{4}{*}{ New Jersey } & $\begin{array}{l}\text { Town Center } \\
\text { DER } \\
\text { Microgrid } \\
\text { Feasibility } \\
\text { Study } \\
\text { Incentive } \\
\text { Program }\end{array}$ & 2016 & $\begin{array}{l}\text { Grants, Loans, and } \\
\text { Other Financing }\end{array}$ & $\begin{array}{l}\text { http://www.njcleanenergy.com/co } \\
\text { mmercial-industrial/programs/der- } \\
\underline{\text { microgrid-feasibility-studies }}\end{array}$ \\
\hline & $\begin{array}{l}\text { New Jersey } \\
\text { Energy } \\
\text { Resilience } \\
\text { Bank }\end{array}$ & 2016 & $\begin{array}{l}\text { Grants, Loans, and } \\
\text { Other Financing }\end{array}$ & $\frac{\text { http://www.nj.gov/bpu/commercial }}{\text { Lerb/ }}$ \\
\hline & $\begin{array}{l}\text { New Jersey } \\
\text { BPU }\end{array}$ & 2016 & Microgrid Roadmap & $\frac{\text { http://www.nj.gov/bpu/pdf/reports }}{\text { /20161130 microgrid report.pdf }}$ \\
\hline & $\begin{array}{l}\text { NJ } \\
\text { TRANSITGRID }\end{array}$ & 2013 & $\begin{array}{l}\text { Grants, Loans, and } \\
\text { Other Financing }\end{array}$ & $\frac{\text { http://njtransitresilienceprogram.co }}{\underline{\mathrm{m} / \mathrm{nj} \text {-transitgrid-overview/ }}}$ \\
\hline \multirow{5}{*}{ New York } & $\begin{array}{l}\text { Assembly Bill } \\
\text { 3004D }\end{array}$ & 2017 & $\begin{array}{l}\text { Grants, Loans, and } \\
\text { Other Financing }\end{array}$ & $\begin{array}{l}\text { http://assembly.state.ny.us/leg/?de } \\
\text { fault fld=\&bn=A03004\&term=2017 } \\
\text { \&Summary=Y\&Actions=Y\&Text=Y\&C } \\
\text { ommittee\%26nbspVotes=Y\&Floor\% } \\
\text { 26nbspVotes=Y\#A03004D }\end{array}$ \\
\hline & NY Prize & 2015 & $\begin{array}{l}\text { Grants, Loans, and } \\
\text { Other Financing }\end{array}$ & $\begin{array}{l}\text { https://www.nyserda.ny.gov/All- } \\
\text { Programs/Programs/NY-Prize }\end{array}$ \\
\hline & $\begin{array}{l}\text { NYSERDA 14- } \\
36 S\end{array}$ & 2014 & Microgrid Roadmap & $\begin{array}{l}\text { https://www.nyserda.ny.gov/- } \\
\text { Lmedia/Microgrids-Report- } \\
\text { Summary.pdf }\end{array}$ \\
\hline & $\begin{array}{l}\text { Reforming } \\
\text { the Energy } \\
\text { Vision (REV) }\end{array}$ & 2014 & $\begin{array}{l}\text { Energy Market } \\
\text { Reform }\end{array}$ & https://rev.ny.gov \\
\hline & $\begin{array}{l}\text { NYSERDA 10- } \\
35\end{array}$ & 2010 & Microgrid Roadmap & $\begin{array}{l}\text { https://www.nyserda.ny.gov/- } \\
\text { Lmedia/Files/Publications/Research/ } \\
\text { Electic-Power-Delivery/microgrids- } \\
\text { value-opportunities-barriers.pdf }\end{array}$ \\
\hline \multirow{2}{*}{ Rhode Island } & $\begin{array}{l}\text { Power Sector } \\
\text { Transformati } \\
\text { on Initiative }\end{array}$ & 2017 & $\begin{array}{l}\text { Energy Market } \\
\text { Reform }\end{array}$ & $\begin{array}{l}\text { http://www.ripuc.org/utilityinfo/ele } \\
\text { ctric/PST\%20Report Nov 8.pdf }\end{array}$ \\
\hline & Celtic Energy & 2017 & Microgrid Roadmap & $\begin{array}{l}\text { http://www.energy.ri.gov/reports- } \\
\text { publications/past-projects/resilient- } \\
\text { microgrids-for-critical-services.php }\end{array}$ \\
\hline Texas & HB 1831 & 2009 & Resiliency Retrofits & $\begin{array}{l}\text { https://capitol.texas.gov/tlodocs/81 } \\
\text { R/billtext/html/HB01831F.HTM }\end{array}$ \\
\hline
\end{tabular}




\begin{tabular}{|c|c|c|c|c|}
\hline & HB 4409 & 2009 & Resiliency Retrofits & $\begin{array}{l}\text { https://capitol.texas.gov/tlodocs/81 } \\
\underline{\text { R/billtext/pdf/HB04409F.pdf\#navpa }} \\
\underline{\text { nes }=0}\end{array}$ \\
\hline & HB 1864 & 2013 & Resiliency Retrofits & $\frac{\text { https://capitol.texas.gov/tlodocs/83 }}{\text { R/billtext/html/HB01864F.HTM }}$ \\
\hline Vermont & $\begin{array}{l}\text { Vermont } \\
\text { Clean Energy } \\
\text { Development } \\
\text { Fund (CEDF) }\end{array}$ & 2015 & $\begin{array}{l}\text { Grants, Loans, and } \\
\text { Other Financing }\end{array}$ & $\begin{array}{l}\text { https://www.cleanegroup.org/ceg- } \\
\text { projects/resilient-power- } \\
\text { project/featured- } \\
\text { installations/stafford-hill/; } \\
\text { http://publicservice.vermont.gov/r } \\
\text { enewable energy/cedf }\end{array}$ \\
\hline Washington & $\begin{array}{l}\text { Clean Energy } \\
\text { Fund }\end{array}$ & 2017 & $\begin{array}{l}\text { Grants, Loans, and } \\
\text { Other Financing }\end{array}$ & $\begin{array}{l}\text { http://leap.leg.wa.gov/leap/budget/ } \\
\text { lbns/1315Cap5035-S.SL.pdf; } \\
\text { http://www.commerce.wa.gov/new } \\
\text { s-releases/community-grants/7- } \\
\text { million-in-state-clean-energy-fund- } \\
\text { grants-advance-microgrid-projects- } \\
\text { at-avista-snopud/ }\end{array}$ \\
\hline
\end{tabular}

